\title{
Responsible Lending Policy of Green Investments in the Energy Sector in Poland
}

\author{
Irena Pyka and Aleksandra Nocoń *D \\ Department of Banking and Financial Markets, Faculty of Finance, University of Economics in Katowice, \\ 40-287 Katowice, Poland; irena.pyka@ue.katowice.pl \\ * Correspondence: aleksandra.nocon@ue.katowice.pl
}

Citation: Pyka, I.; Nocoń, A. Responsible Lending Policy of Green Investments in the Energy Sector in Poland. Energies 2021, 14, 7298.

https://doi.org/10.3390/en14217298

Academic Editor: Beata Zofia Filipiak

Received: 9 October 2021

Accepted: 28 October 2021

Published: 4 November 2021

Publisher's Note: MDPI stays neutral with regard to jurisdictional claims in published maps and institutional affiliations.

Copyright: (c) 2021 by the authors. Licensee MDPI, Basel, Switzerland. This article is an open access article distributed under the terms and conditions of the Creative Commons Attribution (CC BY) license (https:// creativecommons.org/licenses/by/ $4.0 /)$.

\begin{abstract}
The paper concerns the issue of responsible involvement of commercial banks in Poland in green financing of the energy sector. The main reason for undertaking this topic is the observed increased interest of domestic banks in green financing of investments on the energy market in Poland. Therefore, the main objective are to explore the determinants of changes in the level and structure of bank loans under the influence of green investments in the energy sector in Poland. The article verifies the research hypothesis which assumes that an increase in financing green investments by bank loans in the energy market in Poland requires strengthening the synergy of responsible financing of sustainable development of the economy. For this purpose, a two-stage concept of the empirical research was adopted. On the first stage, questionnaire surveys were conducted among the largest Polish commercial banks to examine the respondents' acceptance degree of the concept of sustainable financing and greening the loan portfolio. On the second stage, case studies were analyzed along with the analysis of selected secondary quantitative data. It was proven that commercial banks in Poland increase their commitment to sustainable financing, which is observed in the sectorally progressing process of "greening" the credit offer. There is also a noticeable change in their approach to social responsibility, especially in the context of the energy market, where financing of traditional, ecologically harmful projects is still dominant. However, this trend is slowly being reversed, towards supporting investments in the area of modern, environmentally-friendly energy solutions. However, "greening" of loan portfolios in the native banking sector requires a responsible lending policy based on various complex business decisions. Increasing their pro-ecological awareness of financing the economy is only a prerequisite, albeit inadequate, of further energy transformation in Poland.
\end{abstract}

Keywords: greening bank loans; "green" investments; financing of the energy sector in Poland; sustainable finance; sustainable development; green finance

\section{Introduction}

Responsible banks' lending policies undoubtedly represent a new financial category [1,2], and the interest in the scientific, as well as political and business environment is still growing. It was established in close connection with the increasingly dynamically developing idea of sustainable development (SD) that has been functioning in economic theories for a relatively long time [3-6], but its renaissance has recently been spectacular in EU countries. The reasons for the revival of the concept, aimed at the process of social, economic, and environmental changes ensuring a balance in the fulfillment of the future generations' needs, are very different [7]. Fundamentally, they are associated with the acceleration of civilization development, which, along with a number of achievements, leads to the depletion of natural resources, impoverishment of the biosphere, or disturbance of the ecological balance, causing more and more damage, disasters, and threats [8]. However, reconciling the development of our civilization with the appropriate functioning of the natural environment is a serious challenge for contemporary generations, favoring the creation of new concepts and strategies for sustainable development $[7,9]$. 
In the scientific discussion, attention is drawn to its pluralistic nature, which makes it difficult to crystallize the real features of sustainable development of the economy [8]. It also emphasizes the illusory nature of its effects and costs, which diverse in time and territorial space [10], or their high dependence on the change in the criteria for assessing the realized concept. Moreover, it is noticed that the adaptation of the sustainable development strategy by macro- and micro-economic entities generates high business risk and requires building symptomatic social responsibility in the sphere of their functioning [11]. This responsibility usually refers to a management strategy, i.e., corporate social responsibility (CSR), aimed at increasing the enterprises' competitiveness in the conditions of the sustainable development strategy implementation [12]. On 28 October 2010, the International Organization for Standardization (ISO) published the ISO 26000 standard. This standard organizes the knowledge of corporate social responsibility (CSR), constituting a practical guide to the principles of responsible business [13-15]. In this sense, it is used by banks in their business activities. Responsible lending policy should be based on CRS standards, as, in fact, it refers to the concept of sustainable development. However, its creation should be closely associated with the financing of green investments whose importance in the implementation of the sustainable development strategy in the European Union increased significantly after the 21st Conference of the Parties (COP) in Paris in 2015. At the conference, the EU concept of sustainable development was concretized [16]. However, it did not translate into the development of a comprehensive climate policy investment program in the member states. Therefore, the European Green Deal (EGD) has become an important element of its implementation. The announcement on the European Green Deal was published by the European Commission on 11 December 2019, recognizing that it is the new strategy implemented in the European Union based on its transformation into a socially responsible, green, carbon-free, and non-polluting society [17].

Moreover, the 2030 Agenda for Sustainable Development (SDGs 2030), accepted in 2015, obliged all member states to start real activities aimed at environment protection and development. The aftermath of this is the currently observed the process of green growth, which has gained momentum over the last few years. The literature studies indicate that the main drivers of the sustainable development are green investment [18-22]. On the other hand, a significant part of these investments is being implemented in the field of renewable energy, which aimed at reducing greenhouse gas emissions (GHG emissions) [23-25].

The adopted new regulations hastily passed into the sphere of evaluation of specific solutions for green financing of climate investments, fostering the revival of the discussion and exposition of problems related to sustainable finance [26]. Financial challenges are especially related to climate change which Poland will face in the next 30 years and are estimated at hundreds of billions of Polish zlotys. They concern activities related to the implementation of activities towards stopping climate change, necessary to ensure competitiveness and an adequate quality of life [27]. That is why the following questions arise in public discussion: how do companies perceive the challenges of sustainable development; and how do they respond to social, economic, and environmental challenges? Ref. [28] All the above aspects have become a main motivation for undertaking the research, which is the main subject of the publication's interest, relating to the problems of banks engaging in green financing. This was particularly important given that, as proven, the future of effective energy transformation is mainly based on the methods of its financing $[29,30]$. The biggest concern is that insufficient green financing can threaten the achievements of the green goals [29].

The additional justification is also the assumption that greening investments in EU member states will be a durable procedure, concentrated on gaining capital from nonbanking institutions [25,31,32]. Probing the role of banks in this process seems to complement the knowledge of green financing of investments in the European Union, which determines the originality of the undertaken research topic. Previously conducted research mainly focusses on verifying the hypothesis of financial instability, as well as on maintaining the financial security of global banks [33]. On the other hand, the knowledge about the 
degree and motives of banks' involvement in green financing of investments remains very modest. Meanwhile, in the Polish banking sector, there is an increased interest of domestic banks in green lending of investments. The need for green assets is noticed by more and more domestic banks, following the indications of their strategic partners. However, these are not the only reasons for their interest in green finance. Therefore, the main objective is to explore determinants that create a level and structure of bank loans under the influence of green investments in the energy sector in Poland. The exposure of the importance of the energy sector in the responsible lending policy of domestic banks results, in particular, from the mounting energy problems in Poland. The changes taking place in the Polish energy sector, as well as the long-term but necessary green innovations for domestic banks, are a high-credit risk zone. This is why the publication verifies the research hypothesis that an increase in financing green investments by bank loans in the energy market in Poland requires strengthening the synergy of responsible financing of $\mathrm{SD}$.

The paper has conceptual and empirical nature, which is reflected in the structure of the paper and its following sections. After introduction in the second section, an in-depth review of domestic and foreign literature regarding the issue of SD and its evolution in the context of changes in economic theory, as well as concretization of this concept on a practical and regulatory basis in relation to the assumptions of the energy transformation in Poland, was performed. Potential scenarios for the development of the country's energy sector until 2050 were also presented due to the specificity of the Polish energy market. Later, the attention was focused on green financing of the energy sector and changes in the approach to building the loan portfolio of banking institutions in Poland. The third section of the paper presents the research methodology, where the two-stage research concept and the research methods used during studies were discussed. The course and assumptions of electronic questionnaire surveys conducted among the 10 biggest commercial banks in Poland were outlined. The fourth section provides the results obtained at individual stages of the research, pointing to changes towards greening the loan portfolio of banking institutions in Poland, and supporting capital recipients from the energy sector in the transition to a carbon-free society economy and its sustainable and ecological investments. The last section of the article is a synthetic summary, which contains answers to research questions, which are the result of the conducted research.

The article provides a significant theoretical and application contribution to the discipline of economics and finance. In theoretical terms, it shows the outcomes of a comprehensive investigation of the evolution of the sustainable development concept, including sustainable finance since the 1940s, and the current state of knowledge on possible scenarios of greening bank loan portfolios in Poland. In application terms, it provides the results of extensive empirical research among the largest commercial banks in Poland, which, due to the ongoing energy transformation, must change their corporate format, thus responding to the needs of a dynamically changing environment. The adopted research methodology is undoubtedly innovative, and its application allowed for an in-depth diagnosis of the studied issues.

\section{Literature Review}

Responsible lending policy is a new research problem in the theory of finance and banking [2,34-37]. The literature review has shown that its vision is very closely related to an SD approach, promoting a new orientation in the modern world economy [38]. Its creation is associated with the dynamic development of many countries after the World War Two. Moreover in the 1960s, there was more awareness of environmental protection related to the depletion of natural resources and the progressive degradation of nature, conditioning the economic growth of subsequent generations [39]. The precursors of the awakened ambitions to create a new vision of the world economy were undoubtedly the authors of the disseminated study - the Limits to Growth (LTG) [40], and a broader studyReports to the Club of Rome. Their criticism of the current model of human development, which - due to various factors-led to a serious stratification of rich and poor countries, 
contributed to the creation of new concepts of economic development, usually referring to the differences expressed in the views of previously known philosophers of economic thought [41-43]. Undoubtedly, they include popular anti-globalization and alter-global social movements, which, however, turned out to be inconsistent in their assumptions and based only on contesting the globalization process [44]. In comparison, the concept of sustainable development was considered to be avant-garde. It was created in opposition to the assumptions of A. Smith's classical economy in the version of modern neoliberalism [45] and distanced from globalization as its contemporary form [46]. Sustainable development has also turned out to be a concept of alternative goals of nations development, relating to the economic, social, and environmental spheres (the relative balance of which helps to meet the present society needs without threatening the socio-economic development of future generations) [47-49]. In this way, the idea of sustainable development gained wide support of various economic and political research groups and became a theoretically serious concept in the face of globalization and its neoliberal ideology [46], discussed and developed on many different levels and fields [8,50-57].

The widespread approval of the sustainable development concept has created a strong pressure on its implementation over time. The concretization of the idea of sustainable development is very closely related to the Stockholm Declaration adopted at The United Nations Conference in Stockholm in 1972 [58]. It defines the basic principles of forming society and the world economy, guaranteeing the fulfillment of the sustainable development idea [59]. In their light, the SD approach is defined as the permanent, non-expendable progress of all aspects, referring to responsible ecological, economic, and public policy. The responsible lending policy, based on the concept of sustainable development, appeared in the research space, referring in a spectacular way to its adopted concretization. However, it is becoming increasingly often that serious "negative pluses", noticeable from the perspective of the passing time, turned out to be problematic. They concern ideological assumptions, social benefits, and, above all, the economic rationality of green growth. The approach of SD has not developed its philosophical foundations [44], which causes constant turbulence in identifying its goals and a lack of responsibility for the economic and social costs within its implementation [60]. Social benefits are situated in an undefined future and relate to general environmental matter. In the broad discussion on sustainable development, an increasing number of threats of modern generations are identified, based on the ideology of "fear" that justifies all irrational strategies of wider group of originators. The "supernatural" good, which is the vision of a prosperous, just society with a clean, safe, and healthier environment, obscures the economic principle of rationalization which cannot be contested. The concept of sustainable development takes on-to a larger extent-the features of an utopian theory with an apocalyptic nature. The intention of the expressed opinion is the increasingly stronger polarization between the concept and strategies (which express it) of sustainable development. This problem is not the subject of the study, although it should be exposed, because it causes and promotes irreversible and / or costly (irrational) changes in the modern world economy, including responsible lending policy.

A key element of sustainable development is the concept of sustainable finance (SF) which involves the procedure where ESG purposes are the key determinants in investment decision making in the financial sector [61]. In the literature, the concept of sustainable finance is a broader term that includes climate finance as well as green finance. Climate finance aimed at gathering capital for climate change adjustment and reduction, while green finance is a wider-ranging term which also includes other SD purposes (such as: natural environment safety). It this sense, green finance, which a subject of the main interest in the paper, is understood as a part of the SF [61] and is embedded in a broader 'greening finance' approach, aimed to shift financial flows from brown to green - not only to grow the green niche [62].

The process of greening finance and green financing taking place within green finance are the main drivers within the financial system into its ecologically friendly transformation. 
Green financing concentrates on gathering public as well as private capital to finance green investments. Finally, green financing is also particularly important when it comes to post-pandemic economic restoration [62].

Green financing, provided by green credit products, is defined as a financial innovation, and its implementation in banking sectors is becoming more and more popular on a global scale [63-65]. Green lending fosters to move financing towards ecological sectors, increases the quality of banking products, finances the company's responsible investments, and, finally, supports SD [66]. One the other hand, green lending may determine the level of credit risk undertaken by banks involved in green credit transformation [67]. Finally, which should be particularly emphasized, green credit policy has an important impact on sustainable investments [68].

Meanwhile, in the European Union, wherein Poland is already a long-standing member, the concept of sustainable finance in practice means the obligation of its implementation by European institutions and governments, all countries, societies, as well as enterprises and organizations [26]. Therefore, the importance in the EU environment concretization of this concept, based on the Paris Agreement of 2015, is an unquestionable obligation for the Polish authorities to implement it. However, the Paris Agreement's main purpose, which is to hold further climate perturbation by stopping an global increase in temperature in 21st century "well below 2 degrees Celsius" [69,70], especially for the Polish coal-based economy, not only requires deep, fast, and cost-intensive changes, but also triggers strong social tensions [71].

The scope of necessary changes in Poland is determined by Energy Policy of Poland until 2040 (PEP2040) adopted by the Council of Ministers on 2 February 2021, which is included in The Strategy for Responsible Development [72]. It is an attempt at a comprehensive approach to energy and environmental issues, while remaining compatible with other strategies pursuing the European Union's goals of sustainable development. Scheme 1 presents the approaches to the energy sector transformation in Poland until 2050 [73]. There are many challenges related to the implementation of the adopted scenarios. They concern mutual coherence of the adopted development strategies, both domestically and internationally; the specification of assumptions of the energy development scenario; as well as the identification of tasks in the short and medium term.

However, the forecast of outlays and financial costs of the new Polish energy policy remains a separate issue. It is estimated that a scale of investment outlays in the years between 2021-2040 may reach approximately EUR 350 billion. Investments in the fuel and energy sectors will require EUR 189-194 billion. The planned expenses in the electricity generation sector will cost around EUR 70-75 billion (all the values originally available in PLN were converted into EUR based on the average currency rate on 21 October 2021 (EUR $1=$ PLN 45930)), while around 80\% of them will be used on zero-emission capacities, i.e., renewable energy sources (RES) and nuclear energy [73]. However, the energy transformation will require involvement of many entities, generating financial costs that are difficult to clearly define. The challenge in this area will undoubtedly be the scale and pace of the energy transformation implementation, which will directly depend on the national financial resources allocated for this purpose. Deep transformation must also take place in the fuel and energy sector, which will generate an increase in energy costs. The more ongoing changes there are, the more that energy prices should also be monitored, in order to prevent energy poverty. Otherwise, by taking into account specificity of the Polish energy transformation, there will be strong social resistance with unpredictable dimensions and social costs, contradictory to a responsible lending policy. 


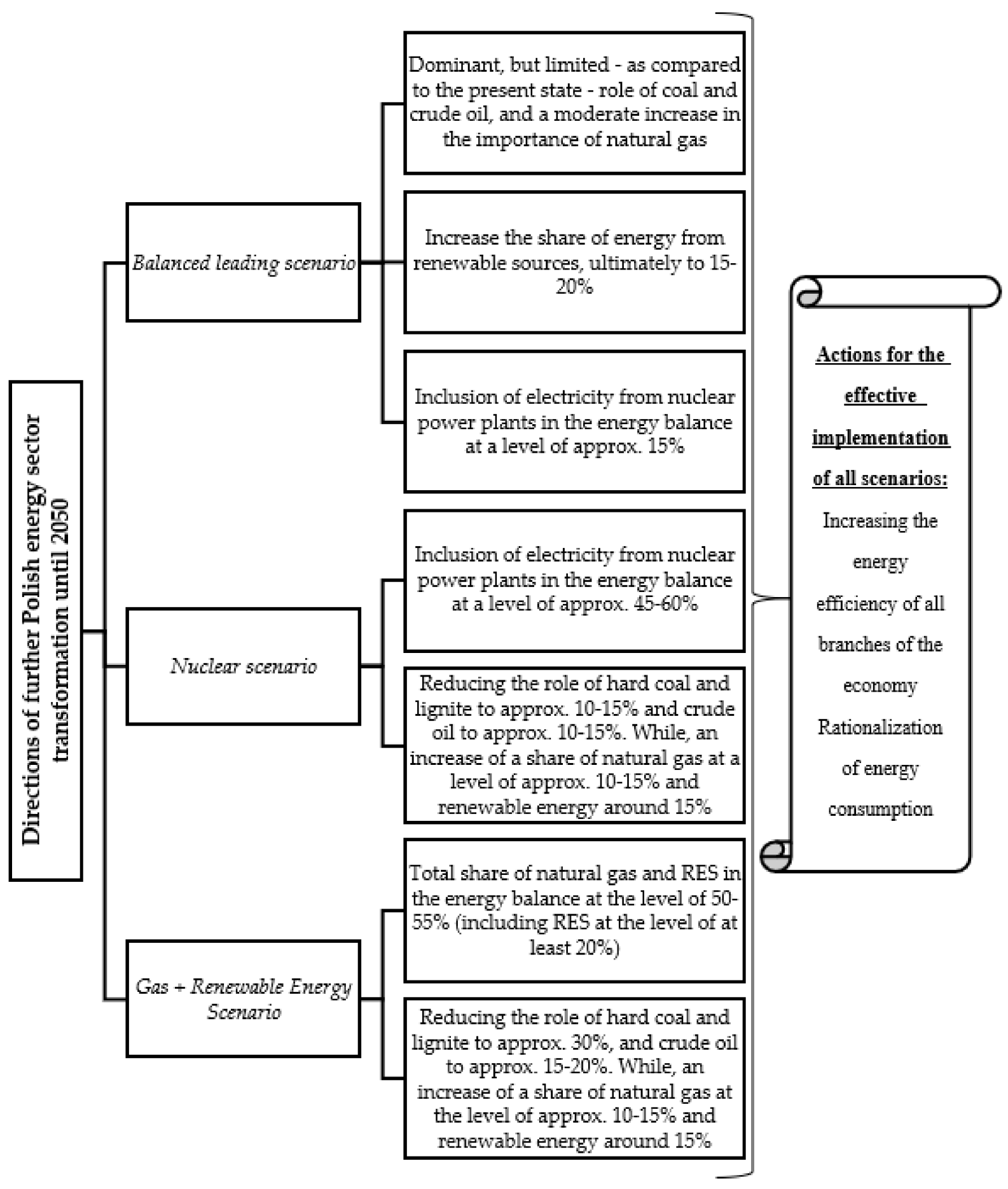

Scheme 1. Scenarios for the Polish energy sector transformation until 2050. Source: own work based on: [74].

Returning to the previously indicated problems of sustainable development, it should be emphasized that, it is assumed that an additional review of EU regulations, concerning energy and climate policy, is planned in the near future. It concerns, in particular, limitations of greenhouse gas emissions by 2050 [75]. The events of the last period (the so-called Timmermans' concept) not only prove the illusory nature of the sustainable development concept, but also the low quality of financial forecasts for its implementation. Estimates of the financial needs of climate change in Poland will not be realistic enough if it is carried out in conditions of unstable strategic assumptions. Meanwhile, in 2019, the European Green Deal (EGD) was implemented [17], which is a direct response to the lack of progress in all European Union countries with regard to the assumptions of climate neutrality adopted by 
the EU until 2050. However, on 15 April 2020, after significant criticism of the EGD, the EU Council presented the EU Taxonomy for SF of green investments [76].

At the same time, accelerating the achievement of climate goals in the EU is taking place in the context of instability of the world economy caused by the coronavirus pandemic. Although the pandemic itself highlights the key position of the energy sector in the functioning of the Polish economy and other European countries, it also presented its post-COVID challenges. In the coming years, the energy sector in EU countries, including Poland, will face the necessity to rebuild and/or substitute supply chains to implement green investments as well as capital allocation in the state budgets affected by the pandemic, or, finally, verify investment plans and collecting financing for ventures, concentrated on green and low-emission growth. In these circumstances, EU support under the prepared economic recovery program (NextGenerationEU) becomes more important [77]. The problem is that their distribution not only postpones in time, but also constantly evokes a number of economic and political emotions. Poland, which has progressed in limiting influence in the energy sector on environment in the last dozen years, by modernizing production capacities and diversifying the structure of energy production, is still very heavily addicted on coal fuels. This makes that it demands a just transformation considering the current position and social aspect of the transformation.

Implementation of the sustainable development concept, taking into account status of its realization, is taking place, and it seems that it will continue to also take place in the conditions of unregulated stability of the world economy after the GFC. The pandemic has brutally interrupted the pro-growth activities of the world's largest economies, including the European Union. However, it is known that the global economy before and after the financial crisis of the 21st century is not the same. First of all, the systemic risk generated by international corporations transferring negative domestic impulses to the world economy was considered a serious threat to the stability of the world economy $[78,79]$. Due to the enormous amount of unprecedented losses, suffered by financial institutions and national economies after the last crises, new arguments were brought against the globalization of the modern economy [80-82]. Therefore, the global financial crisis has become a source of new inspiration for regulatory and institutional changes. However, they refer to the idea of globalism only to a small extent, which is related to a continuation of the neoliberal model of the modern economy, remaining in contrary to the sustainable development concept. Therefore, the fundamental question concerns social costs of this peculiar development mixture. The only answer is and will be time, while the appropriate recommendation can only be the rationality of the undertaken actions.

In such unspecified circumstances, financial institutions, guided by the prepared vision of greening investments in the global economy, take steps to finance them. Mobilization of public funds and market-non-banking financing for this purpose is clearly visible in EU programs. That is why, banks observing changes and penetrating their business models, implement more and more changes in the loan portfolios for their greening. The main motive for changing their lending policy seems to be the investment forecasts of energy companies in Poland, including the four largest energy groups (PGE, Tauron, Enea, and Energa). These enterprises, considering the strategic assumptions of SD in the community, report a high demand for green investments $[83,84]$. In this perspective, they will be forced to use external financing for a significant part of the planned investments. Banks see their place to increase the main parameters of their own operational efficiency in the needs of financing green investments. However, the problem is that the risk of financial involvement in energy investment projects in Poland is high. This is connected with environmental, productive, social, and sectoral aspects. Banks, in the assessment of credit risk of green investments-not only in the energy sector, should learn to quantify and monitor them. In the sectoral area, a large group of risk factors are constantly identified. This especially concerns the lack of legal and regulatory stability. Many investors have failed to invest in renewable energy, mainly because the law has radically changed. In addition to this, there are also other factors of sectoral risk, such as [85]: 
- uncertainty of regulations related to the granting of free $\mathrm{CO}_{2}$ emissions allowances and prices of $\mathrm{CO}_{2}$ emissions allowances;

- a complex liberalization concept in the electricity sales segment;

- an approach to shaping gas prices in contracts for the purchase of fuel after the liberalization of the gas sector in the future;

- expected changes to the current regulations in RES.

The uncertainty of engaging in green energy investments also applies to economic instability. In fact, mainly macroeconomic factors in the economy determine possibilities of financing new investments. In this regard, it is difficult to make good predictions. After the global financial crisis, interest rates on the money market remain low [86,87]. Their long-awaited increase also did not take place as a result of the coronavirus pandemic. However, this increase in interest rates can seriously disturb the financial equilibrium of the EU economy. The consequences of this imbalance are unpredictable. Meanwhile, banks' expectations for an increase in main interest rates translate into higher profits, especially in the RES sector, reducing their interest in coal projects. However, conventional sources in the Polish energy sector also require financial support. Banks cannot and should not reduce their interest in consumer loans. Not only for the pro-growth effect of consumer demand, but also for the financial balance of households. This issue seems to be important in the perspective of a large margin of exclusion (social poverty), and therefore an important area of sustainable development. It is not a subject of the current study, but is important in the context of the undertaken attempt to assess the degree and nature of changes in the bank's responsible lending policy. Multidimensionality of factors, by determining these changes, additionally increases its application value. Therefore, responsible lending policy means optimization of banks' investment portfolios creation, including various needs of SD, and considering factors of their financial security. This approach directed the issues, analyzed in the study, to identification of banks' involvement in green investments in the energy sector, which was a ground for extensive studies. Energy projects applied in Poland for many years should be provided with stable and long-term credit support, implemented under the responsible lending policy.

\section{Materials and Methods}

The empirical part of the studies was designed in two parts to reliably identify the analyzed issues. In the first stage, survey research was conducted, and results from this were thoroughly analyzed and assessed. Then, the results and conclusions drawn on their basis were compared and supplemented in the second stage with data obtained using case studies and explication of secondary quantitative data.

The survey studies were conducted in the second quarter of 2021. Their objective was to identify the degree of greening bank loan portfolios and commercial banks' approach to SF in Poland. The survey was based on collecting data through distributing an electronic questionnaire to respondents, who are responsible for risk management within the commercial banks. There were 129 respondents who participated in the study. They were representatives of banks who work in management, as well as risk management and credit risk analysis departments of the 10 biggest banking institutions. The sample was justified by the fact that, in 2019, the total assets of the 10 largest commercial banks in Poland accounted for $74.29 \%$ of the total assets of the banking sector, and their total assets estimated around EUR 323.61 billion [88]. The other smaller commercial banks, as well as cooperative banks were omitted, because their total assets were estimated to be around quarter of the whole Polish banking sector. It means that the outcomes from a sample are representatives and can be generalized to a meaningful society.

The research was carried out with the use of an electronic questionnaire. A questionnaire was designed after the review of preliminary studies. The survey questionnaire included 36 questions concerning four key areas:

- implementation of the assumptions of sustainable finance in banks;

- a greening loan offer; 
- the financing policy of the energy sector by the Polish banking sector;

- consequences of the coronavirus pandemic for the operation and efficiency of commercial banks in Poland.

The research used a 5-point response scale (Likert scale) to assess a degree of acceptance by respondents of the progress in the implementation of the concept of SF and greening loan portfolio in the banking sector in Poland. For this purpose, 36 microthesis statements were formulated.

In the second stage of the research, results obtained from the survey studies were supplemented by case studies, and also supported by the analysis of selected secondary quantitative data, relating to the issue of sustainable financing and greening bank loan portfolio on the Polish energy market. For this purpose, available secondary quantitative data were analyzed in order to present the significance of the banking sector and "green" credit products as a source of financing the modern energy market in Poland. During the research, data from international databases and scientific publications were used. Furthermore, an analysis of the loan offer of the largest commercial banks in Poland was also carried out in terms of the availability of "green" products. Although, the case study method is widely used qualitative analysis method, which allows to analyze and discuss real situations, as well as make an in-depth analysis of a specific phenomenon, it also has several limitations. They are as follows [89]:

- a too-small scale of the conducted research is associated with an error in the selection of the sample, which results in a too-narrow subjective scope and a too-small number of cases to obtain realistic results (sample selection error). As a result, due to the non-probability of purposeful sampling, the obtained data are less representative than in the quantitative research using random sampling;

- bias in collecting research material, i.e., focusing on facts close to the researcher's position on specific issues or omitting anything that could undermine this position;

- possible misinterpretation of the obtained results

- $\quad$ selective presentation of the research results.

The structure of the research allowed for a comprehensive assessment of the responsible lending policy of green investments in the energy sector in Poland.

Although outcomes of the conducted empirical studies show a good diagnosis of the studied phenomenon as well as the appropriate use of the research method, such as online surveys, which are growing in popularity, mainly because they are an easy, convenient, and inexpensive means of data collection (especially during pandemic times), the following research limitations should also be taken into account. First of all, they are based on the survey conducted with the use of an electronic questionnaire, which generate certain imperfections. A second possible limitation is that, although the research sample was representative, it did not cover all institutions, conducting banking activity in Poland. Therefore, there is a probability that its extension (to for example cooperative banks or smaller commercial banks) may change the final results.

\section{Results}

\subsection{Results from the Survey Research (Stage 1)}

Before assessment of the results of individual questions, the sample was analysed. In the research $67 \%$ of the respondents were women, while $33 \%$ of them were men. The structure of the respondents according to gender is presented in Figure 1. 


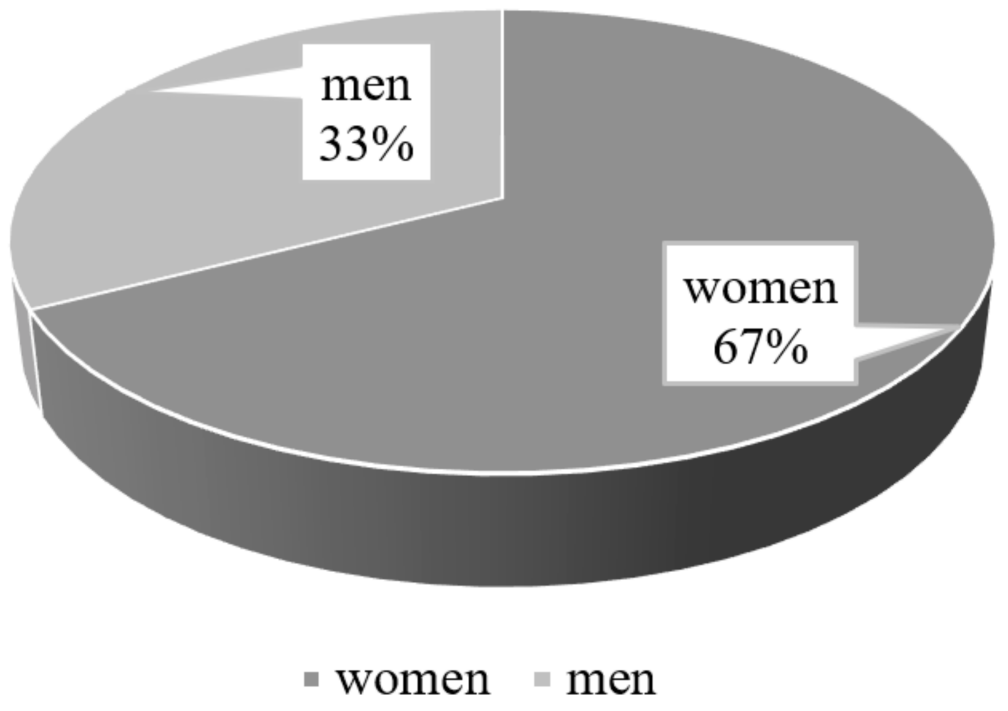

Figure 1. Structure of respondents by gender. Source: own work.

A total of $26.73 \%$ of all respondents represented the management division, while the other ones (73.64\%) held positions responsible for risk management, traditional banking (including retail and corporate banking), credit and financial analysis, transaction monitoring, operational division, and financial reporting. A limitation of this sample is that it was determined by the need to have appropriate knowledge in the field of changes, taking place within the bank's credit offer towards green finance, sustainable finance concept implementation, as well as financing of the energy sector in relation to regulations which have been introduced in recent years. Figure 2 presents structure of respondents according to their experience in the banking industry.

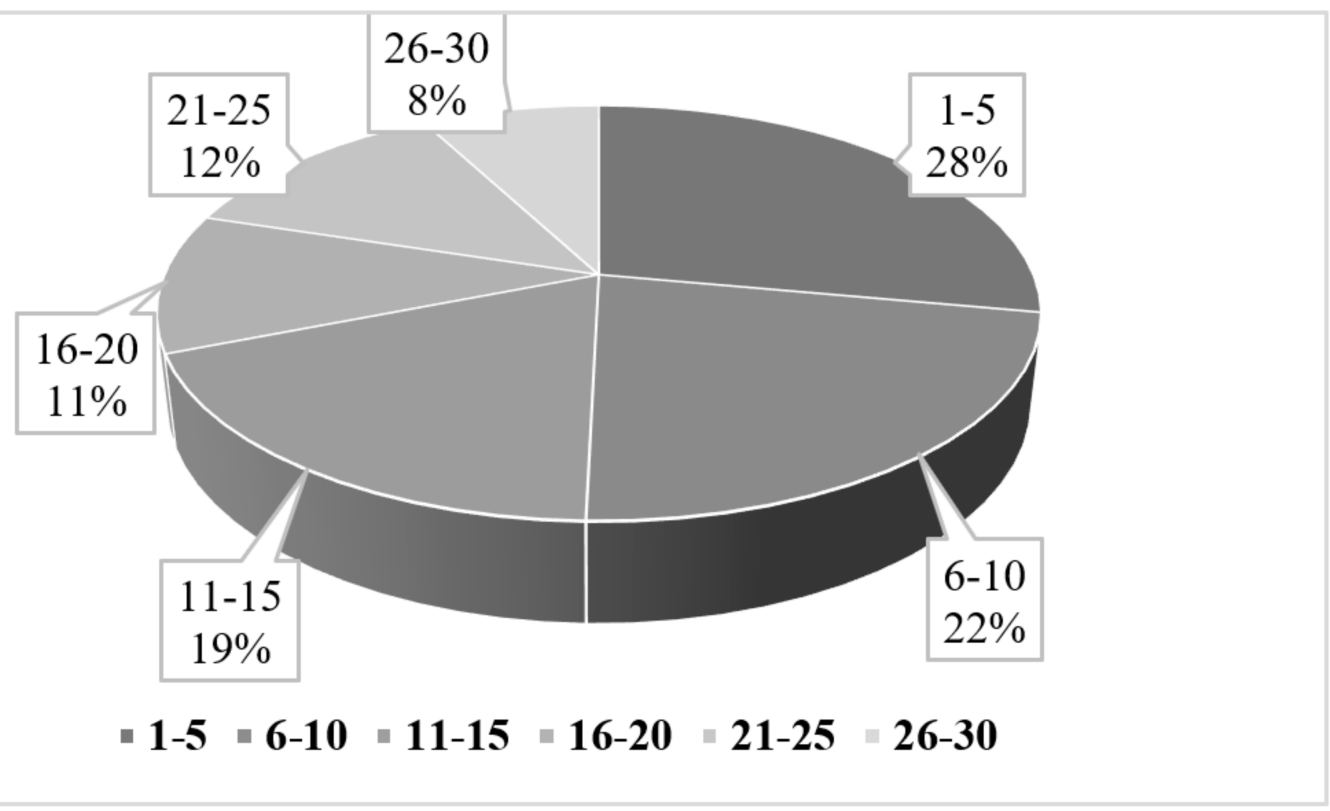

Figure 2. Respondents' experience in the banking industry (in years). Source: own work. 
Then, we assessed the internal consistency of the applied tool using a reliability coefficient-Cronbach's alpha (coefficient alpha). The index may take values in the range from 0 to 1 , while the commonly accepted minimum value of a given factor is 0.6 . Values above 0.6 indicate the correct structure of a questionnaire. However, it is desirable that the value of the factor was close to 1 . The total reliability factor, using Cronbach's alpha for our tool, was 0.9306 for 36 items. This indicates very high internal consistency and, thus, a very good structure of the developed tool.

The conducted empirical research showed that banking institutions are currently at a stage of transformation of their traditional loan offer towards a new approach to sustainable financing. These changes are the result of a global trend to implement the principles of sustainable development. On the European stage, these activities are also a part of the EGD [17]. Sustainable financing, an element of the European Green Deal, for banks means a significant change in the approach to the strategic area of their activities. This involves lending, including modifying the concept of building credit products and assessing credit risk, in relation to the greater responsibility for financed investments [90].

The growing interest in green finance implementation, represented by commercial banks in Poland, was verified by a questionnaire survey, where $62.02 \%$ of respondents indicated that they strongly confirm an increase in the bank's involvement in green finance (see Figure 3). This is also observed in the change in banks' approach to the social responsibility issue and the limitation of traditional, ecologically "harmful" projects of financing. The growing banks' involvement in sustainable finance is also visible in changing their credit offer. Banks in Poland are more and more willing to implement "green" credit products, in turn supporting capital recipients within an environmentally friendly society and in the development of sustainable and ecological investments. Commercial banks in Poland declare that this is an expression of their commitment and responsibility towards the natural environment and the support for borrowers in the energy transformation [91]. Furthermore, $68.99 \%$ of respondents state that their bank's offer includes "green" credit products, granted for the purposes of achieving energy efficiency, renewable energy activities, and water effectiveness (see Figure 4).

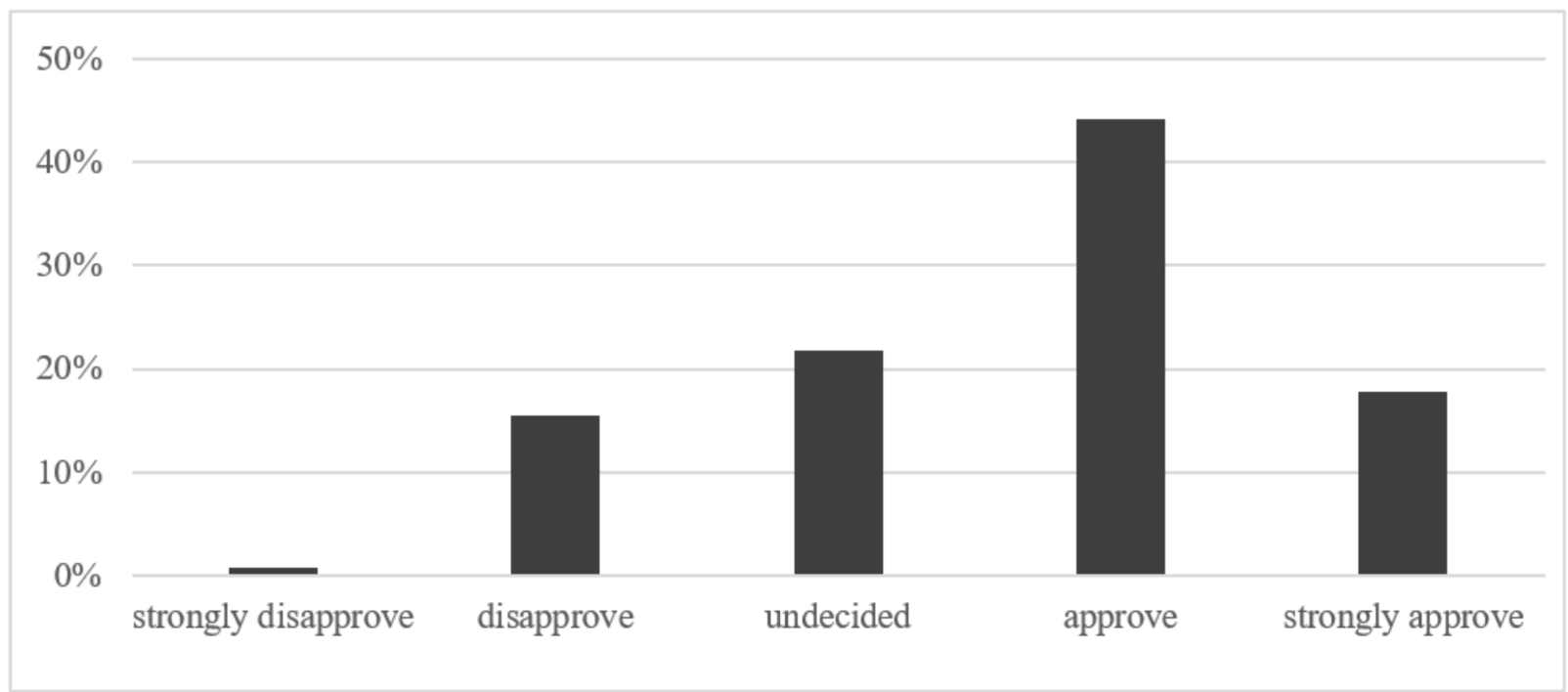

Figure 3. I notice an increase in the involvement of a bank that I represent in green finance (green loans) (in percent). Source: own work. 


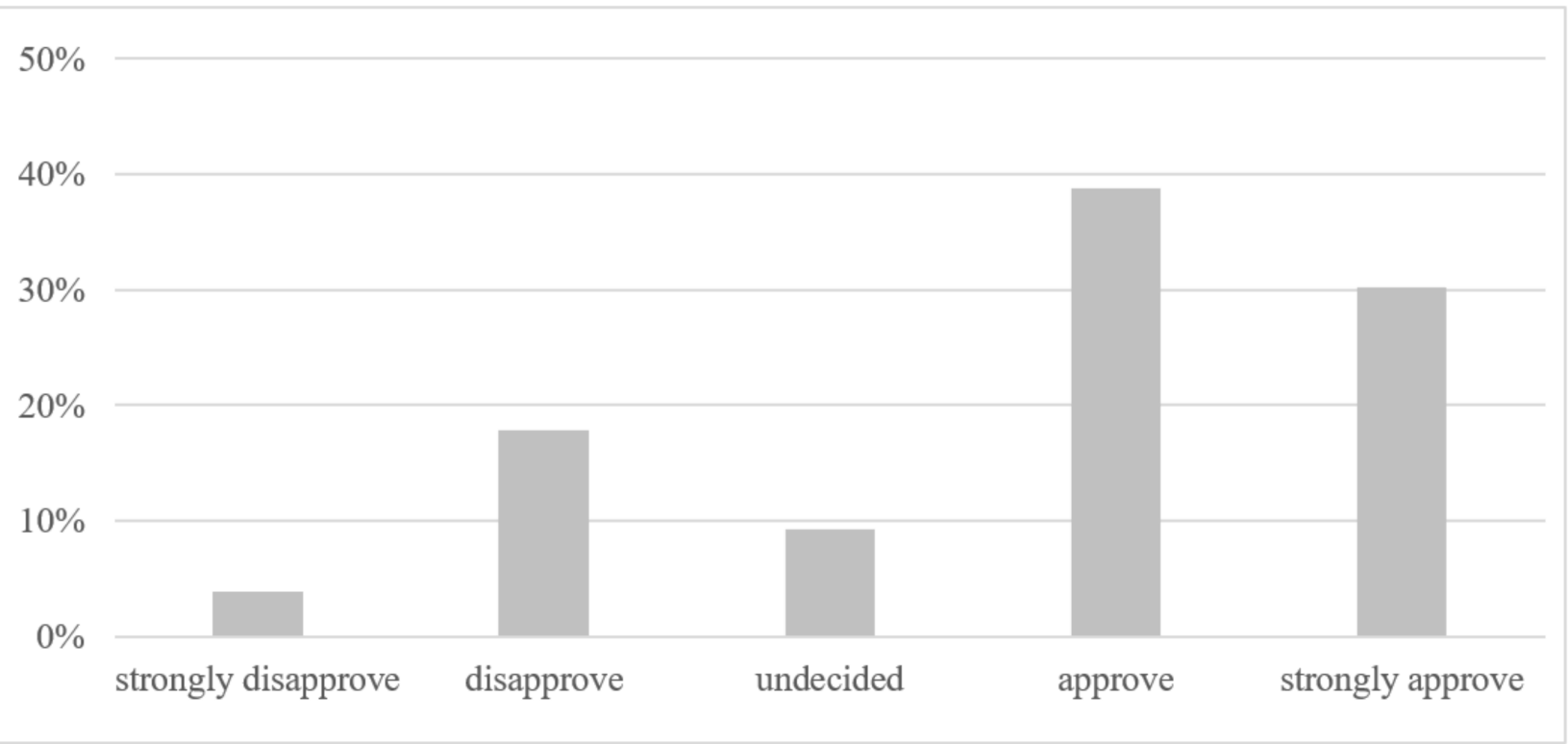

Figure 4. "Green" credit products are available in an offer of a bank that I represent (in percent). Source: own work.

The evolution of green finance in the Polish banking sector increasingly means supporting socially responsible investments. In the context of the energy market, this determines expansion of the banking offer for renewable energy sources financing. However, despite the awareness of a need for consistency of financial flows with objectives of the Paris Agreement $[69,70]$, signed almost six years ago, through decisive actions related to global warming, which are reflected in the higher commitment to sustainable finance, commercial banks in Poland still do not treat financing of green investments as a priority (see Figure 5). Only $35.66 \%$ of the respondents declare that it is the main axis of banks' lending activity. Almost $1 / 3$ of all respondents (30.23\%) do not express an unambiguous opinion on this subject, while $34.11 \%$ of them definitely do not consider green investments financing to be crucial in their operations. This indicates that, although the Polish banking sector is undergoing a transformation towards greening its offer, it is still dominated by traditional banking products and services.

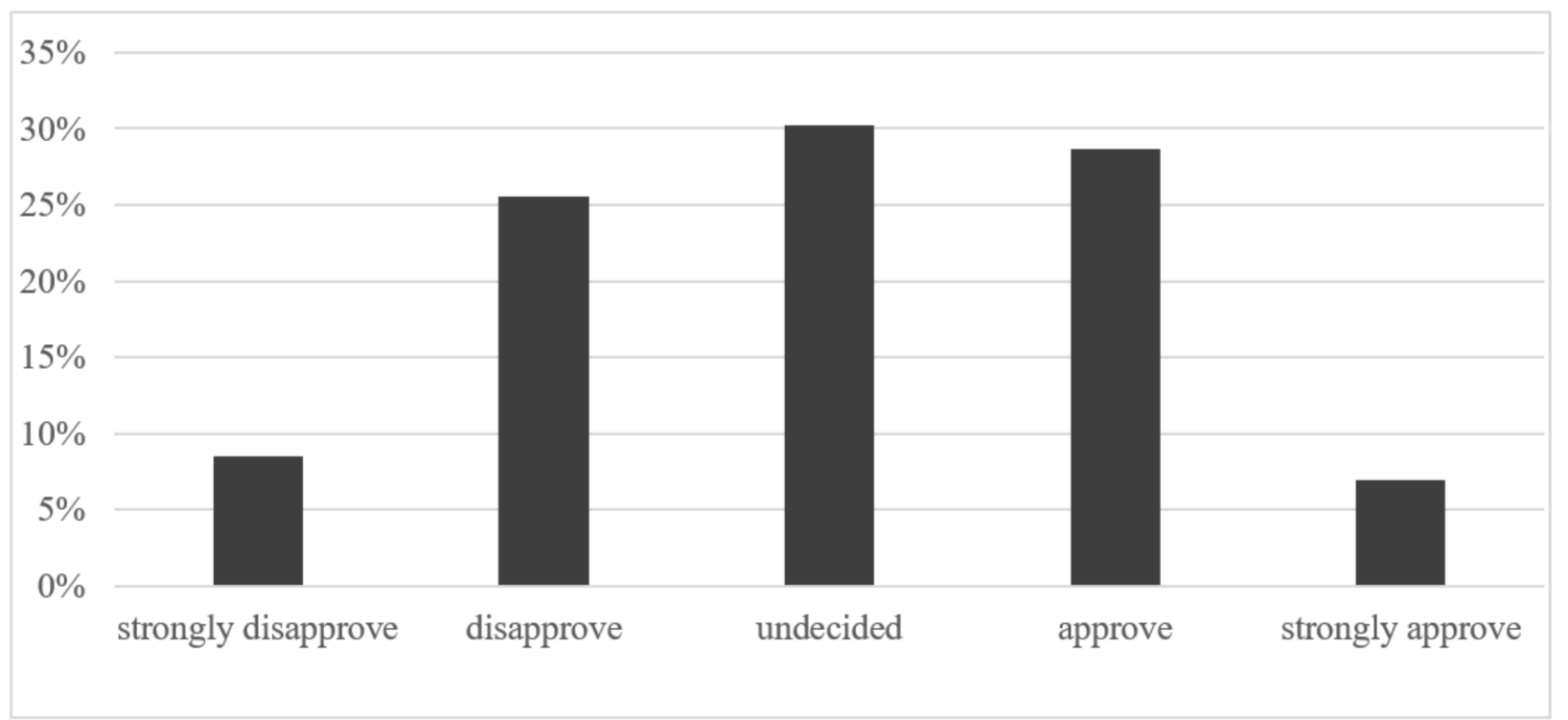

Figure 5. Financing of green investments is treated in a bank, which I represent, as a priority (in percent). Source: own work. 
Moreover, almost half of all survey participants (44.19\%) note that financing investments in the traditional energy sector still represent a significant share in the banks' loan portfolio (see Figure 6). However, it is positive that $38.76 \%$ of the respondents strongly disagree with this statement, indicating the ongoing changes and banks' gradual reduction from financing traditional energy sector. The energy transformation requires banking institutions to fundamentally change the way they operate, and thus time needed to implement a new strategy for their lending policy. It means expansion of a green loans offer, as well as their support in organizing a green bonds issue [31,92]. Taking into account the objective that Europe, which is to become the first continent to achieve net zero greenhouse gas emissions in 2050 [93], a change in the pace of green lending transformation in Polish banks must also take place. Banking institutions should start the process of implementing these changes as soon as possible and transforming them into entities that will fully operate in accordance with the principles of green transformation. This will require them-apart from adjusting their offer-to also acknowledge long-term customer strategies, taking into account climate risk and sustainable development. Therefore, the process of gathering and managing clients' non-financial data, relating to social and environmental aspects, also has to change. This is undoubtedly a major operational and practical change, both for banks as well as for their clients. In the long term, it will cause mutual benefits. Moreover, for banks, a greater focus on the goals of financial investments may lead to lower costs of credit risk. This also represents an opportunity to create bank's image and build long-term relations with the business environment.

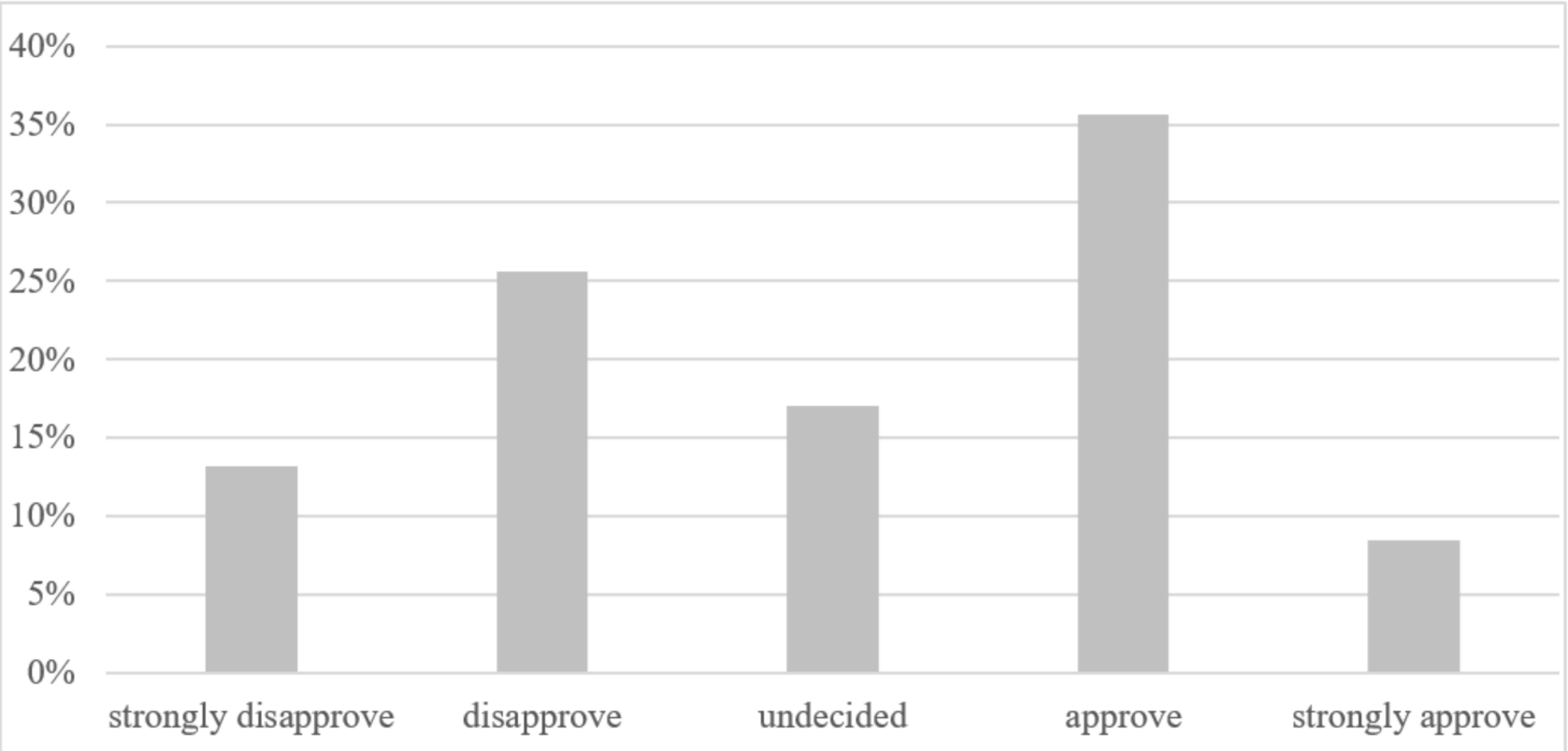

Figure 6. Financing investments in the traditional energy sector still represents a significant share in the banks' loan portfolio (in percent). Source: own work.

In the Polish banking sector, some of these processes are already underway. More than half of the respondents (55.81\%) indicate that banking institutions-in fulfilling the decision of the European Investment Bank (EIB) [94,95] — limit financing of projects from the traditional energy market related to fossil fuels, mainly coal and oil (see Figure 7). This illustrates the evolution of their approach to financing the coal energy sector, as well as intermediaries in this chain. At the same time, this is intended to support a climate-friendly energy policy, including energy efficiency; zero-emission energy supplies; solutions which combine new, low-emission energy sources (renewable energy); and innovations in the field of energy production, its storage, and use. Almost $57.36 \%$ of respondents note that commercial banks in Poland adjust their loan offer to the new energy sector financing policy, established by the EIB (see Figure 8). Thus, the transformation of energy sector 
financing policy illustrates the increasing degree of "greening" loans in Poland. Expansion, adjustment, and greening of the credit offer on the energy market are understood as the transformation of existing products, creation of new ones, but also the ability to obtain and distribute funds from international institutions by banks.

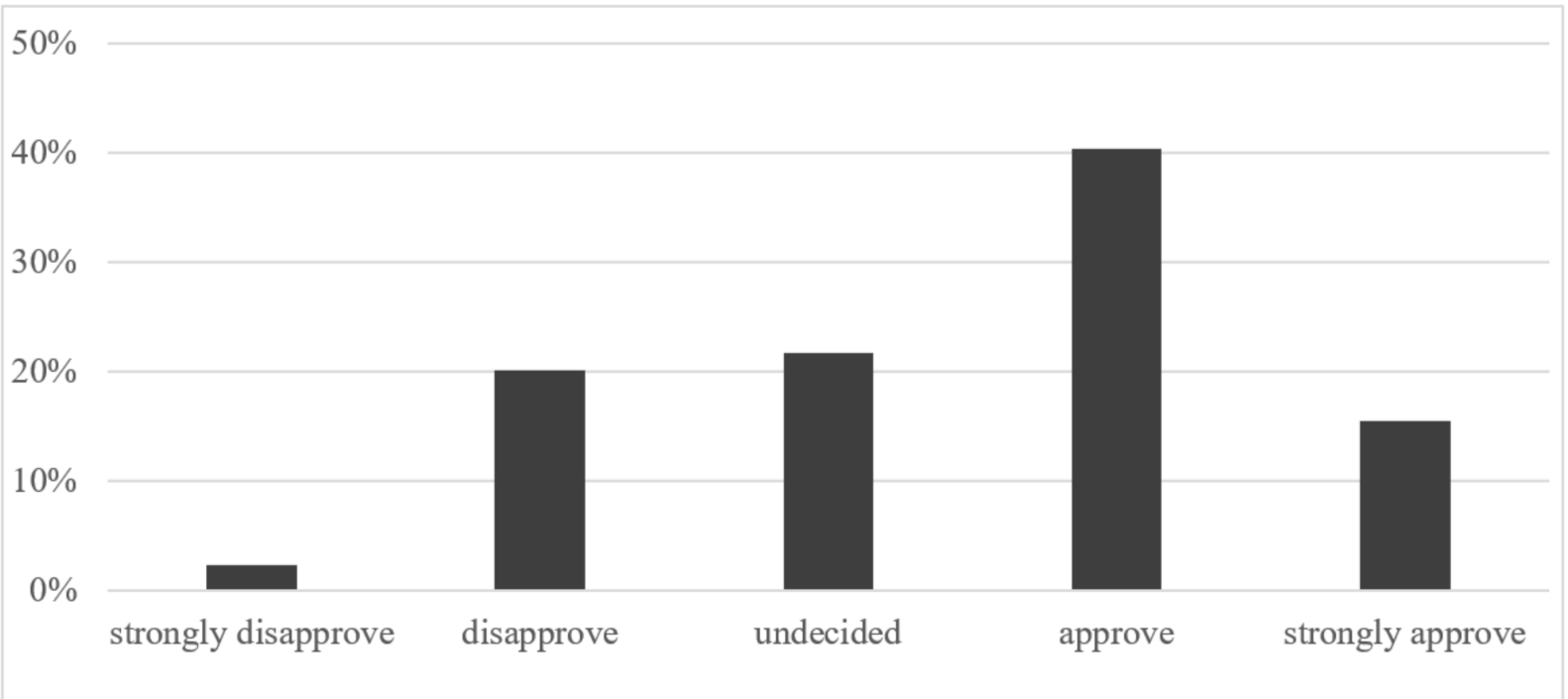

Figure 7. Bank that I represent, in accordance with the decision of the European Investment Bank, limits financing of projects related to fossil fuels, mainly in the field of coal and oil (in percent). Source: own work.

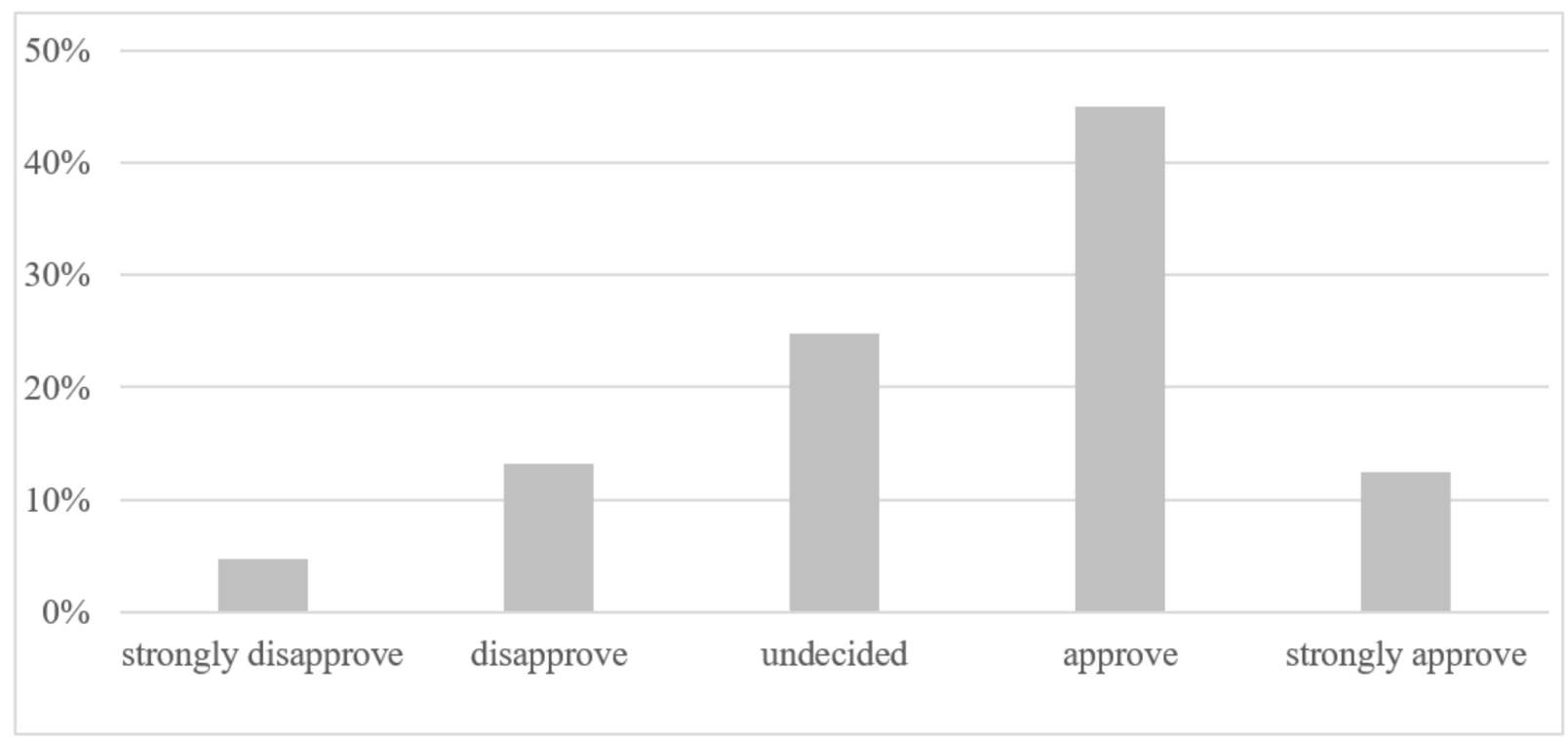

Figure 8. Bank that I represent adjusts its loan offer to the new energy sector financing policy, implemented by the European Investment Bank (in percent). Source: own work.

The ongoing process of greening loans on the energy market in Poland is also represented by the fact that $55.81 \%$ of respondents definitely noticed an increase in financing conceptions including RES, as well as technological innovation, allowing for clean energy production by bank loans (see Figure 9). These are products with lower interest rates compared to traditional loans, extended repayment periods, and preferential conditions for issuing a loan decision and concluding a contract. For banks, this also means changes in the loan application assessment procedure. Currently, only $37.98 \%$ of commercial banks in Poland take into account the $\mathrm{CO}_{2}$ emission factors for investment projects in the energy sector (see Figure 10). In addition, $29.46 \%$ of respondents do not have an opinion on 
this matter, while $32.56 \%$ of them do not confirm such actions of banks in the procedure of loan application assessment. On the other hand, although banks themselves do not have a significant share in $\mathrm{CO}_{2}$ emissions, their financing may affect the development of specific industries.

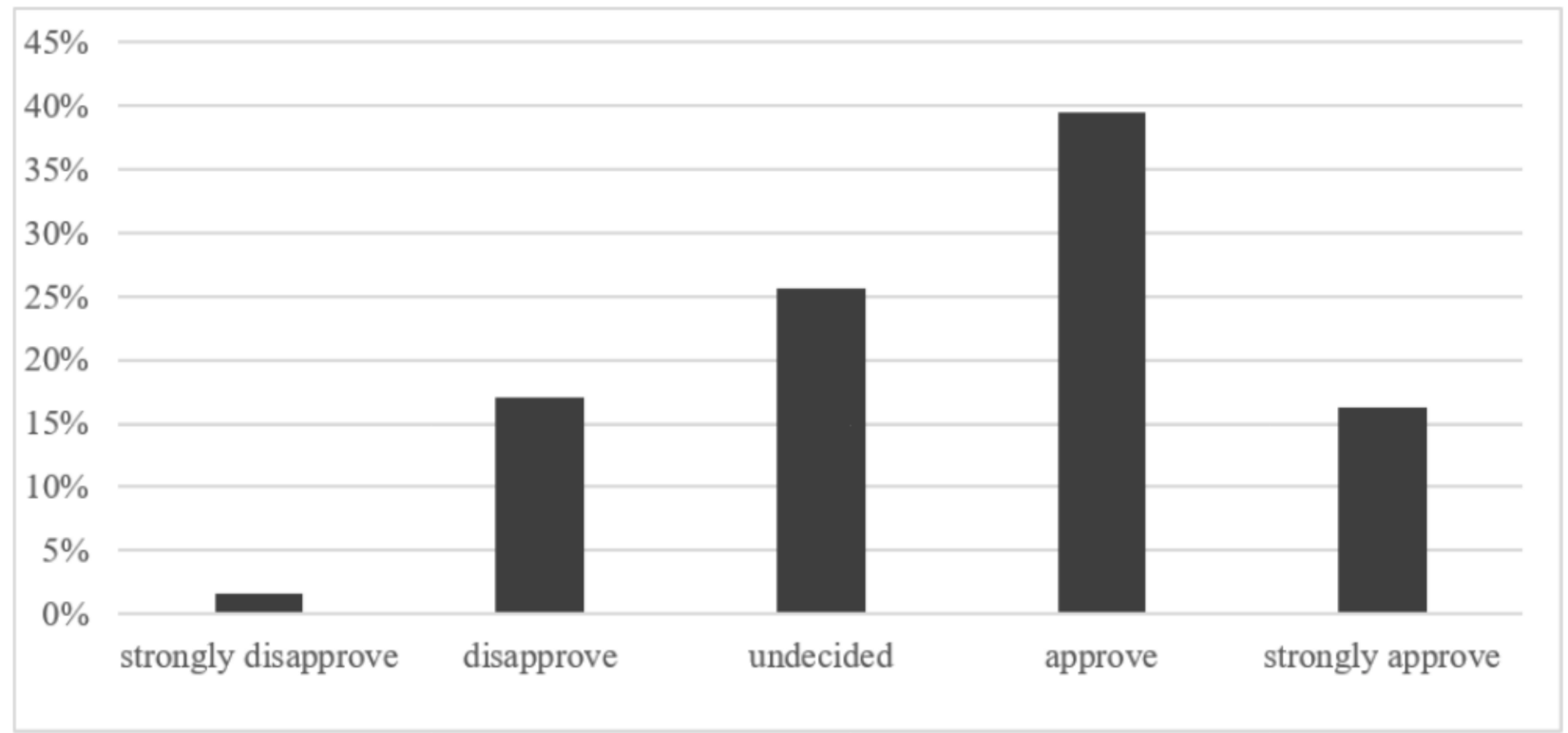

Figure 9. In a bank that I represent, I notice an increase in financing conceptions including RES, energy efficiency, as well as technological innovation, allowing for the production of clean energy, by bank loans (in percent). Source: own work.

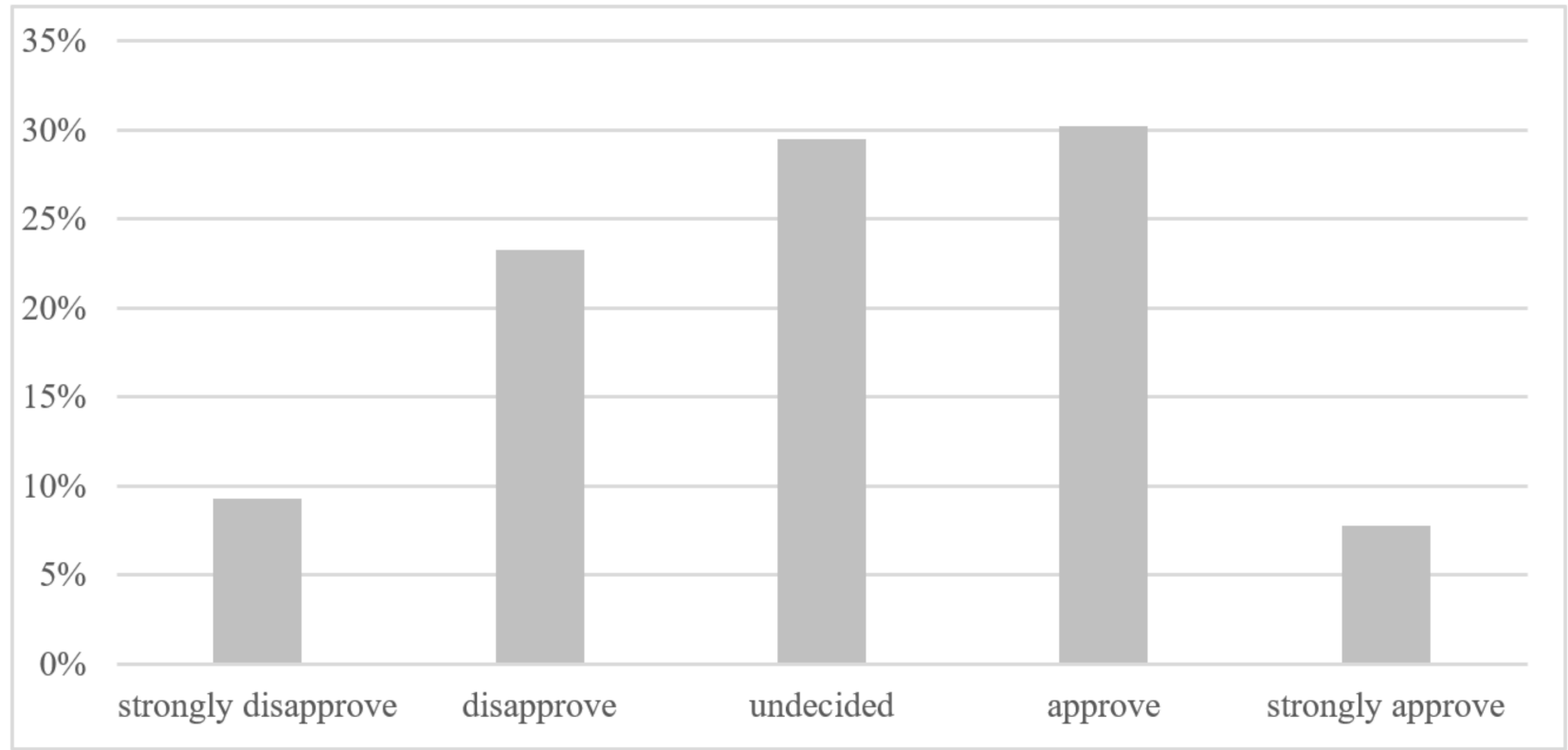

Figure 10. The procedure of loan application assessment in a bank that I represent takes Co2 emission factors into account for investment projects in the energy sector (in percent). Source: own work.

Moreover, it can be expected that the observed changes towards growth of "green" lending products of commercial banks in Poland may have an impact on change in their capital structure (see Figure 11). An argument of this thesis is the possible increase in credit risk and investment risk due to financing of "green" investments on the changing energy market in Poland. However, survey research does not clearly confirm this trend, because only $33.33 \%$ of the respondents confirm this statement, while $34.11 \%$ of them do not have an opinion on this subject, and $32.56 \%$ do not assume changes in the capital structure of a 
bank that they represent. Thus, it is difficult to draw conclusions about any modifications in the capital adequacy. However, in international banking and regulatory environment, there are proposals for recommendations regarding special treatment of green loans for regulatory purposes. For example, the European Banking Federation recommended to the EU bodies that they should amend regulations on capital requirements for financial institutions concerning the preferential treatment of "green" credits for the purpose of calculating capital requirements. These regulations would stimulate the development of sustainable finance in the member states and make it cheaper for borrowers.

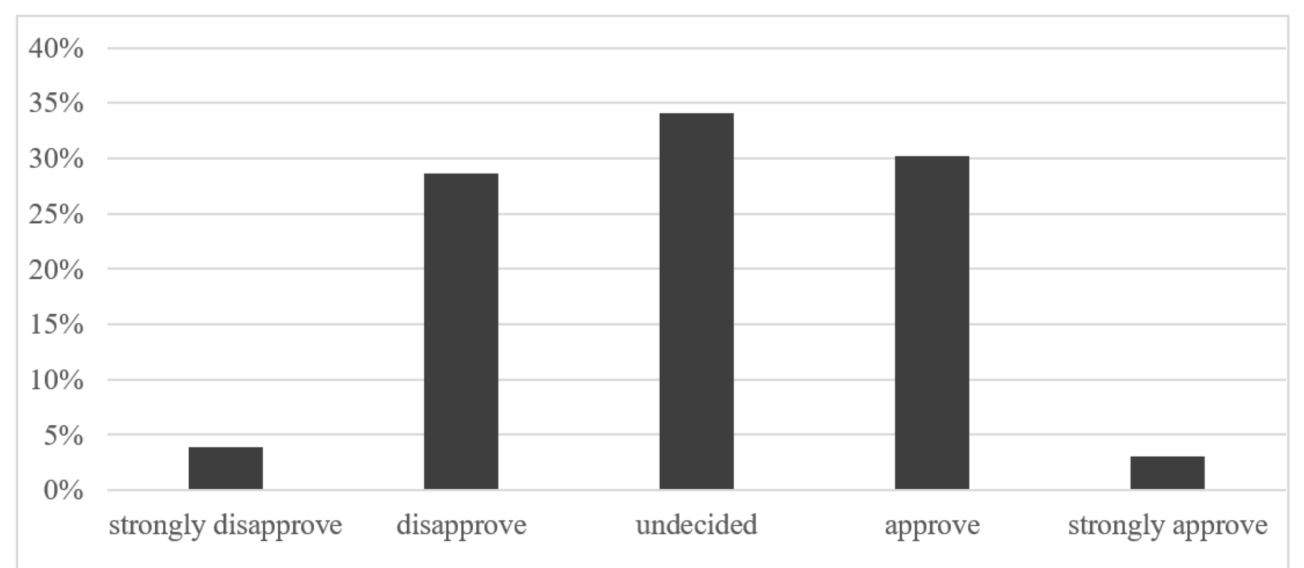

Figure 11. Green investments will change the bank's capital structure (in percent). Source: own work.

However, the period of heightened uncertainty, caused by the coronavirus pan-demic, determines the current implementation of SF concept in Poland. Respondents see an impact of the coronavirus crisis on the strategy of greening Polish banking sector. In fact, $55.81 \%$ of them indicate that the pandemic caused significant consequences in the form of changes the rules of "green" financing of the energy market in Poland (see Figure 12). The implications are two-fold. On the one hand, banks will be more cautious about credit assessment rules of potential projects, which means tightening of the criteria for granting loans, and, on the other hand, the pandemic affected financial stability of many entities, including those operating on the energy sector, which may reduce their creditworthiness and, in a way, oblige banks to grant high-risk loans.

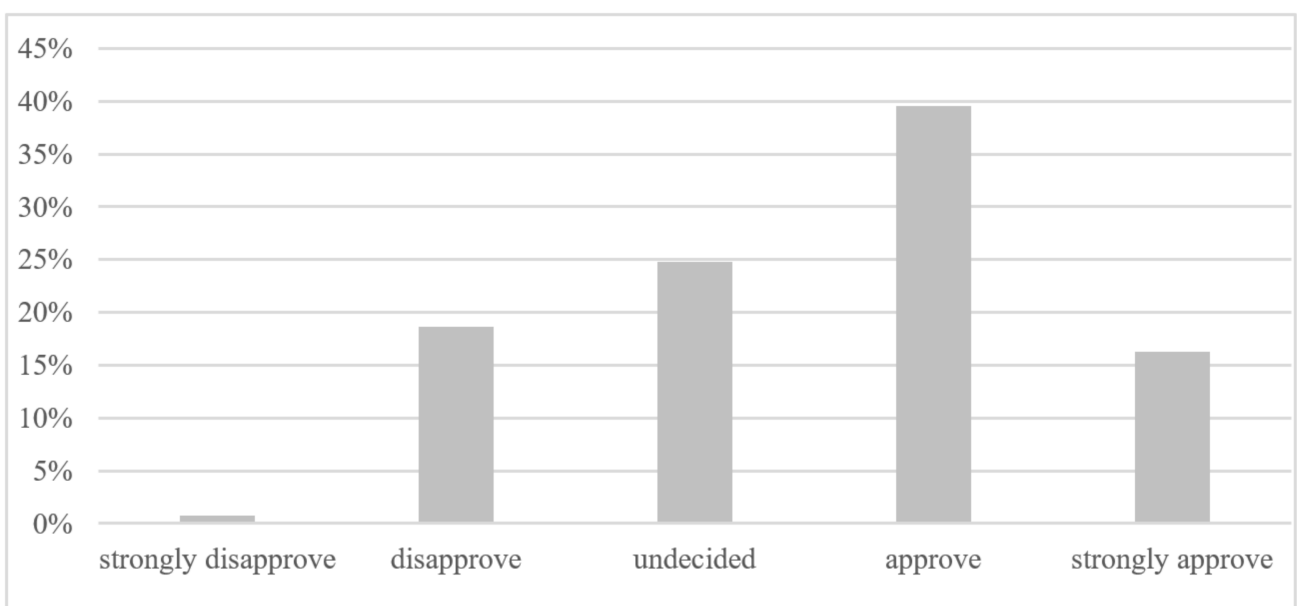

Figure 12. Consequences of the coronavirus pandemic will affect the bank's strategy of green financing (in percent). Source: own work.

\subsection{Results from the Case Studies and Quantitative Data Analysis (Stage 2)}

The second stage of empirical studies that was concentrated on quantitative data analysis as well as case studies showed that the banking sector in the last decade was growing, 
and -in the coming decade-will also remain the leader in financing renewable energy in Poland [96]. Data presented in the "Financing of the investments in renewable energy by Polish banks" report showed that the value of "green" lending between 2013-2019 was on the average level of EUR 0.91 billion per year, which accounted for more than a half of the total funds allocated to financing renewable energy sources (RES) installations. Moreover, an upward trend is observed every year. In 2019, banks provided EUR 2.26 billion of the total EUR 3.42 billion spent on this purpose [97]. Credits and loans were the most important source of financing investments in the area of the modern energy market, apart from bond issuance, leasing, project finance, public-private partnership, or still unused VC/PE funds and hybrid instruments (see Scheme 2). From a bank's perspective, credits and loans for financing investments on the modern energy market are characterized by the lowest risk, while having a positive impact on their image and reputation. On the other hand, high-value investment loans, to the greatest extent, support the energy transformation (commercial banks in Poland can act on the energy market, not only as credit capital providers, but also as organizers of debt securities issuance (ordinary or green bonds), their buyers, or issuers). Other sources play a negligible role in Poland.

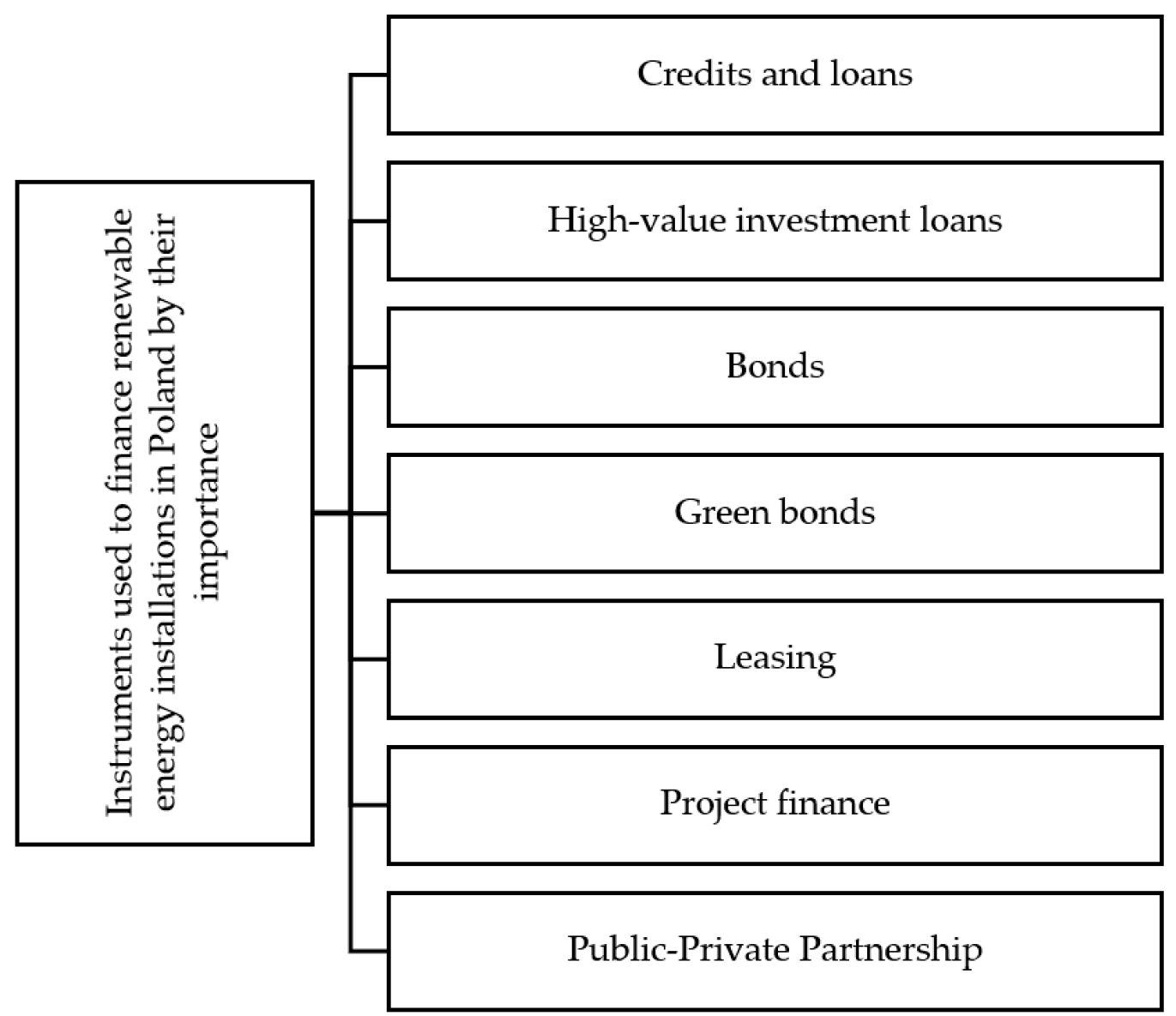

Scheme 2. Instruments used to finance renewable energy installations in Poland by their importance. Source: own work based on: [96].

According to data presented in this report, the involvement of banks in Poland in financing the renewable energy market will systematically increase until 2035 [96]. However, assuming the scenario of accelerated transformation of the Polish energy market for the next 15 years, minimum involvement of the Polish banking sector is required at a level of approximately EUR 1.1 billion per year. Thus, this trend cannot diminish.

The process of "greening" loan offers, taking place initially among only few commercial banks in Poland, is also required from other market participants to adapt to the new trends. It is currently observed that more and more commercial banks in Poland are 
implementing "green" credit products for financing renewable energy investments (see Table 1). Banks with their parent companies abroad are pioneers in this area, because they can gain knowledge and know-how from their headquarters, which have more experience in the implementation of the assumptions of sustainable finance concept.

Table 1. "Green" credit products included in the lending offer of commercial banks in Poland (source: own work).

\begin{tabular}{|c|c|c|c|c|c|}
\hline \multirow{3}{*}{ 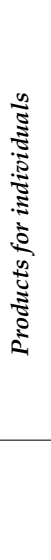 } & $\begin{array}{c}\text { BNP Paribas Bank Polska } \\
\text { (owned by BNP Paribas, French } \\
\text { capital) }\end{array}$ & $\begin{array}{c}\text { ING Bank Śląski } \\
\text { (owned by ING Groep NV, } \\
\text { Dutch capital) }\end{array}$ & $\begin{array}{c}\text { Credit Agricole (owned by } \\
\text { Crédit Agricole, French } \\
\text { capital) }\end{array}$ & $\begin{array}{l}\text { PKO Bank Polski } \\
\text { (Polish Capital) }\end{array}$ & $\begin{array}{c}\text { Boś Bank } \\
\text { (Polish Capital) }\end{array}$ \\
\hline & $\begin{array}{l}\text { - Credit for green changes, } \\
\text { including replacement of heat } \\
\text { sources, modernization and } \\
\text { insulation, modern } \\
\text { technologies (including } \\
\text { photovoltaic panels, thermal } \\
\text { solar collectors, ventilation } \\
\text { with heat recovery } \\
\text { Installment loan for financing } \\
\text { ecological energy sources }\end{array}$ & $\begin{array}{l}\text { Cash loan for } \\
\text { environmental } \\
\text { purposes (including } \\
\text { purchase of energy } \\
\text { saving systems) }\end{array}$ & $\begin{array}{ll}\text { - } & \begin{array}{l}\text { Loan for an ecological } \\
\text { house } \\
\text { (energy-saving) }\end{array} \\
-\quad \text { Consumer loan for } \\
\text { financing renewable } \\
\text { energy sources }\end{array}$ & $\begin{array}{l}\text { Eco-loan for } \\
\text { purchase of } \\
\text { photovoltaic } \\
\text { panels }\end{array}$ & $\begin{array}{l}\text { Eco-loan for } \\
\text { purchase and } \\
\text { assembly of a } \\
\text { photovoltaic } \\
\text { installation }\end{array}$ \\
\hline & $\begin{array}{c}\text { BNP Paribas } \\
\text { (owned by BNP Paribas, French } \\
\text { capital) }\end{array}$ & $\begin{array}{c}\text { ING Bank Śląski } \\
\text { (owned by ING Groep NV, } \\
\text { Dutch capital) }\end{array}$ & $\begin{array}{c}\text { mBank } \\
\text { (owned by Commerzbank, } \\
\text { German capital) }\end{array}$ & $\begin{array}{l}\text { Bank Millenium } \\
\text { (owned by Banco } \\
\text { Comercial Portugues, } \\
\text { Portuguese capital) }\end{array}$ & $\begin{array}{c}\text { Boś Bank } \\
\text { (Polish capital) }\end{array}$ \\
\hline 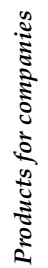 & $\begin{array}{l}\text { Leasing for photovoltaic } \\
\text { "Green Energy"-investment } \\
\text { loan for financing the } \\
\text { construction of wind, hydro } \\
\text { and photovoltaic power plants } \\
\text { as well as installations for } \\
\text { generating electricity, and/or } \\
\text { heat energy from biomass or } \\
\text { biogas }\end{array}$ & $\begin{array}{l}\text { Eco-loan for } \\
\text { companies that invest } \\
\text { in ecological } \\
\text { solutions }\end{array}$ & $\begin{array}{l}\text { Investment loan for } \\
\text { financing renewable } \\
\text { energy sources } \\
\text { (including wind } \\
\text { farms or photovoltaic } \\
\text { installations) }\end{array}$ & $\begin{array}{l}\text { Technological } \\
\text { loan for } \\
\text { financing } \\
\text { implementation } \\
\text { of an } \\
\text { environmentally } \\
\text { friendly } \\
\text { technological } \\
\text { investment }\end{array}$ & $\begin{array}{l}\text { Eco } \\
\text { investment } \\
\text { loan to gain } \\
\text { independence } \\
\text { from energy } \\
\text { prices }\end{array}$ \\
\hline
\end{tabular}

The process of increasing the bank's social involvement usually begins with the adoption and publication of a strategic document which includes the objectives of sustainable development and defines the main activities aimed at reducing financing of projects based on a traditional energy market (the so-called "dirty" energy). In these strategies, banks declare active participation in the implementation of sustainable finance assumptions in the energy industry, through active financing of RES, supporting global operations, aimed at achieving climate neutrality. ING Bank Ślaski also indicated in the Ecological Declaration that, after 2025, it will not finance clients whose activities are directly dependent on steam coal to a degree higher than 5\%. In March 2019, PKO Bank Polski announced that it limits its involvement in the high-carbon energy sector in favor of financing zeroemission or low-emission energy sources. In his lending policy, Pekao adopted a reduction in financing coal mining and energy production from fossil fuels (oil, coal), in order to grow the scale of financing energy from RES [98]. Furthermore, BNP Paribas, one of the leaders of commercial banks in Poland in terms of the variety of "green" loan products, in addition to the offer for individual and business customers, also implemented loans and credits for farmers, including the Agro Progres loan (an investment loan for the purchase or installation photovoltaic installation) and a loan to finance energy-saving agricultural machinery and equipment.

The second stage of the research confirmed the results and conclusions obtained from the survey studies. They indicate an ongoing process of the "greening" loan offer in Poland, which supports energy transformation towards a higher share of the RES in the Polish industry.

\section{Discussion and Conclusions}

Banks' lending policies, assessed in the studies regarding assumptions of SD approach, including EGD - the new vision of the European Union for economic growth, taking climate neutrality into account, indicate a progression towards financing green investments in 
the Polish economy. Banks are entities which, in accordance with the intention of the European Commission and due to insufficient public funds in the EU, play an important role in redirecting financing from high-carbon sectors towards low-carbon ones and energy transformation. Nevertheless, a redirection of capital flows towards more sustainable investments creates a real impact on financial institutions activities, especially in the area of their investment and credit policy. The conducted empirical research has shown that banks themselves increase their involvement in sustainable finance, which is seen in the sectorally progressing process of "greening" their loan offer. However, the energy transformation requires a fundamental change in their business models from banking institutions, adapted to the assumptions of implementing new strategies of their lending policy. Currently, there is a noticeable change in their perspective on social responsibility, especially in the context of an energy market, where-according to the obtained results-financing of traditional, ecologically harmful projects is still dominant. Nevertheless, this trend is slowly being reversed towards supporting investments in the area of modern, environmentally friendly energy solutions. This means that banking institutions in Poland are aware of a need for rapid changes and their inclusion in the systemic (comprehensive, holistic) approach of all EU actions and policies to build a green deal, which-apart from sustainable finance-also includes climate, environmental, energy, transport, industrial, and agricultural policies [26]. Therefore, increasing banks' awareness seems to be an important prerequisite for further energy transformation in Poland, financed by a domestic banking sector.

These changes are undoubtedly also the result of regulations implemented by the EU institutions, ordering to limit the financing of projects related to fossil fuels. Commercial banks in Poland are scrupulously adjusting to them. Empirical studies have also indicated that the main channel of "green" financing is a bank loan, which is more competitive than traditional credit products. Commercial banks in Poland, supporting the energy transformation, also mediate in the procedure of bond issues, including green bonds, or joining public-private partnerships [31]. As far as possible, it also seems that banks will expand their offer of "green" financing, as long as the pandemic crisis does not permanently affect their financial stability and the financial condition of capital recipients. Thus, the conducted empirical research helped to achieve this main purpose of the manuscript.

However, considering that lending policy is a unique and individualized economic existence, which includes various regulatory activities focused on balancing a credit market, in the conditions of enormous financial needs of the whole energy sector in Poland, it should be responsible. Responsible lending policy is undoubtedly an important element of CSR, the formula of corporate social responsibility (in the analyzed banking case). Nevertheless, its implementation requires many activities undertaken by banks in the scope of creating appropriate CSR, corporate governance in banks' operational activities, their product policy (deposit and credit policy, but not only), banks' influence on natural surroundings, as well as a sphere of employment. Responsible lending credit policy is strongly associated with sustainable development; however, to a greater extent, it concerns the implementation of regulatory requirements and, less so, a new approach to business operation. From a perspective of financing green investments in the energy sector, the problem seems to be extremely important for several reasons:

- The scale and quality of capital necessary for financing green investments;

- The risk of changes in the loan portfolio as a result of financing green investments;

- The increased responsibility in entering into contracts with clients;

- The securing of bank procedures in relation to new types of bank risk;

- New product offers.

As a part of responsible lending policy, banks must not also forget that their stakeholders also pursue their own lending policy. In particular, on a free financial market dominated by large corporations, they choose the most advantageous offers, bypassing the credit selection mechanism. The more that this occurs within a free financial market, banks' stakeholders can obtain non-banking capital, to a greater extent. Banks often eliminate lending to business entities, guided at least by a misconception about the poor quality 
of potential loan collateral, negative experiences of refusal to grant a loan in the past or problems with separating company's assets from owner's assets [99]. With regard to green investments, this financing is assumed to be non-bank and hybrid capital. Therefore, banks, in noticing business benefits of financing green investments, should follow a responsible lending policy based on effective counteraction of risk factors related to ESG issues. One of the main forms of risk in a responsible lending policy is the risk of investments in green assets. It arises when the criteria for green investments classification are not sufficiently understood or recognized. In such a situation, bank's investments in green assets may reduce their profitability or omit opportunities for attractive green investments. A responsible lending policy should undoubtedly remain sensitive to business model risks as well as regulatory risks. Business model risks are related to a change in the bank's strategic decisions, which should balance the bank's investment portfolio against green assets and an appropriate rate of return. Responsible lending policies should also take into account regulatory risks. These risks are related to banking legislation, banking supervision and prudential regulations for green investment financing, but also to their lack, misidentification or implementation at an inappropriate time. Banks involved in green financing, in their responsible lending policy, should include indicated new types of risk in the bank risk management system. These risks are often in a simple correlation with the whole spectrum of factors generating controlled types of bank risk. Sustainable development risks may lead to violations of environmental or social norms and standards, or may be associated with inappropriate market practices. These risks may also indirectly increase banks' operational risk. Moreover, the responsible lending policy is based on the monetary policy, conducted by central banks. Commercial banks are model-dependent and strongly determined by its direction, as well as on the implemented supervisory and regulatory changes, to a significant extent by determining business benefits from financing green investments. Therefore, green banking assets in the discussed context determine the implementation of the European Green Deal, but also change the environmental conditions for crediting green investments. The expected changes may limit the competitiveness of economies, such as Poland, and make them dependent on importing low-emission technologies. Indirectly, it may cause an increase in the scale of energy poverty in Poland. It is also important to have the political and social support of most of the EU member states for this sustainable development concept. The prolonged period of green investments implementation in EU countries is conducive to growing doubts about the European Green Deal and arousing social emotions. In Poland, green investments, in accordance with the adopted assumptions of PEP2040, are based on hybrid financing from the state budget, expenses of general government units, European funds, and other foreign resources. A significant part of these expenses will be covered by funds from the fuel and energy sector companies as well as other private funds or debt financing. Banks entering the field of green investments, according to the conducted research, should take into account problems of the state budget in Poland resulting from hybrid financing. It is because the conditions of the budget balance are difficult to define from a long-term perspective. Market resources for financing green investments also remain problematic. Savings of domestic entities are constantly insufficient in relation to the needs of financing their investments in the conditions of the dynamically developing the Polish economy, which may interfere with the process of European Green Deal implementation in Poland. The consequences of the difficulties faced by the Polish economy as a result of the European Parliament questioning the financial post-COVID support for Poland are particularly important. On the other hand, market-based financing can turn out to be very expansive. The cost of domestic loan capital, due to the normalization and tightening of the National Bank of Poland monetary policy, may also increase independently, leading to a slowdown in green investments. The research carried out in the publication only indicates that domestic banks are joining the greening of their assets earlier than the PEP2040 perspective. Therefore, the question arises to what extent do they take into account the aspects of political risk in creating responsible 
lending policy and whether they should assess this risk due to the credit financing horizon shorter than the perspective of PEP2040.

The adopted research methodology helped to deeply recognize this undertaken topic. Quantitative analysis, along with qualitative analysis (case studies), provided a broad perspective of the changes ongoing in the Polish energy market and transformation towards responsible lending policy of commercial banks in Poland. Nevertheless, it has some limitations, previously indicated, which encourage an expansion of research in the future. Furthermore, results of the conducted empirical research, as well as broad international literature review, raise new research questions that may constitute a basis for further in-depth research. It is worth paying attention to the following ones:

1. To what extent does the development of "green" loan offer in Poland depend on regulatory support?

2. To what extent does the "greening" of the loan offer positively affect operational effectiveness of Polish banking sector?

3. Does financing of "green" investments require mitigation of bank risk aimed to a greater extent at limiting its effects in the banking system than securing it with bank capital?

4. To what extent does the pressure of domestic banks on financing projects related to stopping climate change conducive to introduce SF assumptions, and more broadly, sustainable development in Poland?

Author Contributions: Conceptualization, I.P.; methodology, A.N.; software, A.N.; validation, I.P. and A.N.; formal analysis, I.P. and A.N.; resources, I.P. and A.N.; writing—original draft preparation, I.P. and A.N.; writing - review and editing, I.P. and A.N.; visualization, A.N.; supervision, I.P. All authors have read and agreed to the published version of the manuscript.

Funding: The APC was funded by the University of Economics in Katowice.

Institutional Review Board Statement: Not applicable.

Informed Consent Statement: Not applicable.

Data Availability Statement: The data presented in this work were produced by the authors, mainly through survey research. The other data were prepared through case study analysis based on the banks' websites.

Conflicts of Interest: The authors declare no conflict of interest.

\section{References}

1. OECD. Sustainable Lending. Available online: https://www.oecd.org/trade/topics/export-credits/sustainable-lending/ (accessed on 9 September 2021).

2. World Bank. Responsible Lending Overview of Regulatory Tools; World Bank: Washington, DC, USA, 2013.

3. Von Carlowitz, H.C. Sylvicultura economica-Oder Anweisung zur wilden Baumzucht. Nachdr. Ausg. 2000, 1713, 1-53.

4. Daly, H. (Ed.) Towards a Steady State Economy; Freeman: San Francisco, CA, USA, 1973.

5. Daly, H. Beyond Growth - The Economics Of Sustainable Development; Beacon Press: Boston, MA, USA, 1996.

6. Diwan, R.K.; Livingston, D. Alternative Development Strategies and Appropriate Technology; Pergamon Press: New York, NY, USA, 1979

7. Bac, D.P. A history of the concept of sustainable development: Literature review. Ann. Univ. Oradea Econ. Sci. Ser. 2008, 17, $581-585$.

8. United Nations. Report of the World Commission on Environment and Development: Our Common Future; Brundtland Report; UN Documents Gathering a Body of Global Agreements; United Nations: New York, NY, USA, 1987.

9. United Nations. Challenged and Strategies for Sustainable Development in Latin America and the Caribbean; United Nations Sustainable Development Group for Latin America and the Caribbean: Panama, 2018.

10. Ma, Z.; Cheng, M.; Wang, M. Strategic research on the sustainable development cost of manufacturing industry under the background of carbon allowance and trade policy. AIP Conf. Proc. 2017, 1864, 020197.

11. ConocoPhilips. Managing Sustainable Development Risks. Available online: https://www.conocophillips.com/sustainability/ integrating-sustainability/managing-sustainable-development-risks / (accessed on 9 September 2021).

12. European Commission. Corporate Social Responsibility: A New Definition, a New Agenda for Action; MEMO/11/730; European Commission: Brussels, Belgium, 2011. 
13. International Organization for Standardization. ISO 26000:2010. Guidance on Social Responsibility. Available online: https: //www.iso.org/standard/42546.html (accessed on 1 October 2021).

14. Porter, M.E.; Kramer, M.R. Tworzenie wartości dla biznesu i społeczeństwa [Creating value for business and society]. Harv. Bus. Rev. Pol. 2011, 5, 62-77.

15. Rok, B. Społeczna odpowiedzialność przedsiębiorstw w kontekście strategii osiagania obopólnej korzyści. Res. Pap. Wrocław Univ. Econ. 2008, 5, 76-85.

16. UNFCCC. Conference of the Parties, Adoption of the Paris Agreement, 12 December 2015; U.N. Doc. FCCC/CP/2015/L.9/Rev/1; United Nations: New York, NY, USA, 2015.

17. European Council. European Green Deal. Available online: https://www.consilium.europa.eu/pl/policies/green-deal (accessed on 1 October 2021).

18. Raszkowski, A.; Bartniczak, B. Towards sustainable regional development: Economy, society, environment, good governance based on the example of Polish regions. Transform. Bus. Econ. 2018, 17, 225-245.

19. Dalevska, N.; Khobta, V.; Kwilinski, A.; Kravchenko, S. A model for estimating social and economic indicators of sustainable development. Entrep. Sustain. Issues 2019, 6, 1839-1860. [CrossRef]

20. Dabyltayeva, N.; Rakhymzhan, G. The green economy development path: Overview of economic policy priorities. J. Secur. Sustain. Issues 2019, 8, 643-651. [CrossRef]

21. Brożyna, J.; Mentel, G.; Szetela, B. Renewable energy and economic development in the European Union. Acta Polytech. Hung. 2017, 14, 11-34.

22. Matuszewska-Janica, A.; Żebrowska-Suchodolska, D.; Mentel, G. Evaluation of short-term relationships between selected investment funds and the capital market in Poland. Acta Polytech. Hung. 2019, 16, 25-41.

23. Sadorsky, P. Renewable energy consumption, $\mathrm{CO}_{2}$ emissions and oil prices in the $\mathrm{G} 7$ countries. Energy Econ. 2009, 31, 456-462. [CrossRef]

24. Chang, M.C.; Shieh, H.S. The relations between energy effciency and GDP in the Baltic Sea Region and Non-Baltic Sea Region. Transform. Bus. Econ. 2017, 16, 235-247.

25. Lyeonov, S.; Pimonenko, T.; Bilan, Y.; Štreimikienè, D.; Mentel, G. Assessment of green investments' impact on sustainable development: Linking gross domestic product per capita, greenhouse gas emissions and renewable energy. Energies 2019, $12,3891$. [CrossRef]

26. Pyka, I.; Nocoń, A. Banks' capital requirements in terms of implementation of the concept of sustainable finance. Sustainability 2021, 13, 3499. [CrossRef]

27. Kotecki, L. (Ed.) Zielone Finanse w Polsce [Green Finance in Poland]. European Financial Congress. Available online: https: //www.efcongress.com/wp-content/uploads/2020/10/publikacja_zielone_finanse-nowa-wersja.pdf (accessed on 23 October 2021).

28. United Nations. World Economic and Social Survey 2013. Sustainable Development Challenges; E/2013/50/Rev. 1, ST/ESA/344; Department of Economic and Social Affairs: New York, NY, USA, 2013.

29. Taghizadeh-Hesary, F.; Yoshino, N. Sustainable solutions for green financing and investment in renewable energy projects. Energies 2020, 13, 788. [CrossRef]

30. Donovan, C.W. Renewable Energy Finance: Powering the Future; World Scientific Books, World Scientific Publishing Co., Pte. Ltd.: Singapore, 2015; p. 1030.

31. Leitao, J.; Ferreira, J.; Santibanez-Gonzalez, E. Green bonds, sustainable development and environmental policy in the European Union carbon market. Bus. Strategy Environ. 2021, 30, 2077-2090. [CrossRef]

32. European Commission. Communication from the Commission to the European Parliament, the European Council, the European Economic and Social Committee and the Committee of the Regions; The European Green Deal, COM(2019) 640; European Commission: Brussels, Belgium, 2019.

33. Flejterski, S. Stabilny i zrównoważone system finansowy z perspektywy zrównoważonego rozwoju ekonomicznego [Stable and sustainable financial system from the perspective of sustainable economic development]. Stud. Mater. Fac. Manag. Adm. Pedagog. Univ. Jan Kochanowski Kielc. 2017, 21, 97-105.

34. Mak, V. What is responsible lending? The EU consumer mortgage credit directive in the UK and The Netherlands. J. Consum. Policy 2015, 38, 411-430. [CrossRef]

35. Financial Services Users Group. Responsible Consumer Credit Lending. Available online: https://ec.europa.eu/info/ sites/default/files/business_economy_euro/banking_and_finance/documents/fsug-opinions-190408-responsible-consumercredit-lending_en.pdf (accessed on 27 September 2021).

36. Westpac Group. Responsible Lending Policy Manual. July 2017. Available online: https:/ / financialservices.royalcommission.gov. au/public-hearings / Documents/exhibits-2018/21-march/EXHIBIT-1-141-36.pdf (accessed on 27 September 2021).

37. Australian Securities \& Investments Commission. Regulatory Guide 209: Credit Licensing: Responsible Lending Conduct. December 2019. Available online: https:/ / asic.gov.au/media/5403117/rg209-published-9-december-2019.pdf (accessed on 27 September 2021).

38. Skvarciany, V.; Jurevičienè, D.; Volskytè, G. Assessment of sustainable socioeconomic development in European Union countries. Sustainability 2020, 12, 1986. [CrossRef]

39. European Environment Agency. 1960s. Available online: https://www.eea.europa.eu/environmental-time-line/1960s (accessed on 4 October 2021). 
40. Meadows, D.H.; Meadows, D.L.; Randers, J.; Behrens, W. Granice Wzrostu. Raport dla Klubu Rzymskiego [Limits of Growth. Report to the Club of Rome]; PWE: Warsaw, Poland, 1973.

41. Schumacher, E.F. Małe Jest Piękne [Small Is Beautiful]; The State Publishing Institute PIW: Warsaw, Poland, 1981.

42. Toffler, A. Trzecia Fala [Third Wave]; KURPISZ Publishing House: Poznań, Poland, 2006.

43. Malthus, T.R. Prawo Ludności [Population Law]; Jirafa Roja Publishing House: Warsaw, Poland, 2007.

44. Gawor, L. Antyglobalizm, alterglobalizm i filozofia zrównoważonego rozwoju jako globalizacyjne alternatywy [Antiglobalism, alterglobalism and the philosophy of sustainable development as globalization alternatives]. Probl. Sustain. Dev. 2006, 1, 41-48.

45. Pawłowski, A. Wielowymiarowość rozwoju zrównoważonego [The multidimensional nature of sustainable development]. Probl. Sustain. Dev. 2006, 1, 23-32.

46. Papuzinski, A. Filozoficzne aspekty zasady zrównoważonego rozwoju. Zrównoważony rozwój a iustica socialis. In Filozoficzne, Społeczne i Ekonomiczne Uwarunkowania Zrównoważonego Rozwoju; Pawłowski, A., Ed.; Monographs of the Committee on Environmental Engineering of the Polish Academy of Sciences: Lublin, Poland, 2004; Volume 26, pp. 51-71. Available online: https:/ / repozytorium.ukw.edu.pl/bitstream/handle/item/7428/Papuzinski_Filozoficzne_001.pdf?sequence=1\&isAllowed=y (accessed on 27 October 2021).

47. United Nations. What Are the Sustainable Development Goals? Available online: https://www.undp.org/sustainabledevelopment-goals (accessed on 4 October 2021).

48. Taylor, S.J. A Review of Sustainable Development Principles: Centre for Environmental Studies; University of Pretoria: Pretoria, South Africa, 2016.

49. Kluza, K.; Zioło, M.; Bak, I.; Spoz, A. Achieving environmental policy objectives through the implementation of sustainable development goals. The case for European Union countries. Energies 2021, 14, 2129. [CrossRef]

50. United Nations. Transforming Our World: The 2030 Agenda for Sustainable Development; A/RES/70/1; United Nations: New York, NY, USA, 2015.

51. Emas, R. The concept of sustainable development: Definition and defining principles. Brief GSDR 2015, 2015, 1-3. [CrossRef]

52. Strange, T.; Bayley, A. Sustainable Development: Linking Economy, Society, Environment; OECD Insights: Paris, France, 2008.

53. Mensah, J.; Casadevall, R.S. Sustainable development: Meaning, history, principles, pillars, and implications for human action: Literature review. Cogent Soc. Sci. 2019, 5, 1653531. [CrossRef]

54. Allen, C.; Metternicht, G.; Wiedmann, T. Prioritising SDG targets: Assessing baselines, gaps and interlinkages. Sustain. Sci. 2018, 14, 421-438. [CrossRef]

55. Brodhag, C.; Taliere, S. Sustainable development strategies: Tools for policy coherence. Nat. Resour. Forum 2006, 30, 136-145. [CrossRef]

56. Dixon, J.A.; Fallon, L.A. The concept of sustainability: Origins, extensions, and usefulness for policy. Soc. Nat. Resour. 1989, 2, 73-84. [CrossRef]

57. Ukaga, O.; Maser, C.; Reichenbach, M. Sustainable development: Principles, frameworks, and case studies. Int. J. Sustain. High Educ. 2011, 12. [CrossRef]

58. European Commission. Stockholm convention on persistent organic pollutants. Off. J. Eur. Union 2001, 95, 692-708.

59. Rosicki, R. Międzynarodowe i europejskie koncepcje zrównoważonego rozwoju [International and European concepts of sustainable development]. Sci. Methodol. Rev. 2010, 4, 44-56.

60. Vorisek, D.; Yu, S. Understanding the Cost of Achieving the Sustainable Development Goals; Policy Research Working Paper; World Bank: Washington, DC, USA, 2020; p. 9164.

61. European Commission. What Is Sustainable Finance? Available online: https://ec.europa.eu/info/business-economy-euro/ banking-and-finance/sustainable-finance/overview-sustainable-finance_en (accessed on 26 October 2021).

62. Kahlenborn, W.; Cochu, A.; Georgiev, I.; Eisinger, F.; Hogg, D. Defining "Green" in the Context of Green Finance; Final Report; European Commission: Brussels, Belgium, 2017.

63. Zhang, K.; Wang, Y.; Huang, Z. Do the green credit guidelines affect renewable energy investment? Empirical research from China. Sustainability 2021, 13, 9331. [CrossRef]

64. $\mathrm{Xu}, \mathrm{S}$. International comparison of green credit and its enlightenment to China. Green Financ. 2020, 2, 75-99. [CrossRef]

65. He, L.Y.; Zhang, L.H.; Zhong, Z.Q.; Wang, D.; Wang, F. Green credit, renewable energy investment and green economy development: Empirical analysis based on 150 listed companies of China. J. Clean. Prod. 2019, 208, 363-372. [CrossRef]

66. He, L.Y.; Liu, R.Y.; Zhong, Z.Q.; Wang, D.Q.; Xia, Y.F. Can green financial development promote renewable energy investment efficiency? A consideration of bank credit. Renew. Energy 2019, 143, 974-984. [CrossRef]

67. Cui, Y.J.; Geobey, S.; Weber, O.; Lin, H.Y. The impact of green lending on credit risk in China. Sustainability 2018, 10, 2008. [CrossRef]

68. Kang, H.; Jung, S.Y.; Lee, H. The impact of green credit policy on manufacturers' efforts to reduce suppliers' pollution. J. Clean. Prod. 2020, 248, 8. [CrossRef]

69. European Council. Paris Agreement on Climate Change. Available online: https://www.consilium.europa.eu/en/policies/ climate-change/paris-agreement/ (accessed on 8 October 2021).

70. The Council of the European Union. The UN Climate Change Conference (COP21) Paris 2015. Available online: www.consilium. europa.eu (accessed on 19 January 2021). 
71. Commission Staff Working Document Impact Assessment. Accompanying the Document. Proposal for a Directive of the European Parliament and of the Council Amending Directive 2012/27/EU on Energy Efficiency; SWD/2016/0405 Final-2016/0376 (COD); European Commission: Brussel, Belgium, 2016.

72. Ministry of Climate and Environment. Energy Policy of Poland until 2040 (PEP2040); Annex to Resolution No. $22 / 2021$ of the Council of Ministers of 2 February 2021; Ministry of Climate and Environment: Warsaw, Poland, 2021.

73. Announcement of the Minister of Climate and Environment of 2 March 2021on the Energy Policy of Poland until 2040; Monitor Polski: Warsaw, Poland, 2021.

74. Ciechanowska, M. Polityka energetyczna Polski do 2050 roku (energy policy of Poland until 2050). Nafta-Gas 2014, 11, 839-842.

75. European Commission. Communication from the Commission to the European Parliament, the European Council, the Council, the European Economic and Social Committee, the Committee of the Regions and the European Investment Bank. A Clean Planet for All. A European Strategic Long-Term Vision for a Prosperous, Modern, Competitive and Climate Neutral Economy; COM(2018) 773; European Commission: Brussels, Belgium, 2018.

76. European Commission. Communication from the Commission to the European Parliament Pursuant to Article 294(6) of the Treaty on the Functioning of the European Union Concerning the Position of the Council on the Adoption of a Regulation of the European Parliament and of the Council on the Establishment of a Framework to Facilitate Sustainable Investment 2018/0178 (COD), and Amending Regulation 2019/2088 on Sustainability-Related Disclosures in the Financial Services Sector; COM/2020/155 Final; European Commission: Brussels, Belgium, 2020.

77. European Commission. NextGenerationEU. Funding Strategy. 14 April 2021. Available online: https://ec.europa.eu/info/sites/ default/files/about_the_european_commission/eu_budget/factsheet_1_funding_strategy_20.04.pdf (accessed on 9 September 2021).

78. Karkowska, R. Ryzyko Systemowe, Charakter i Źródła Indywidualizacji w Sektorze Bankowym [Systemic Risk, the Nature and Sources of Individualization in the Banking Sector]; Wolters Kluwer: Warsaw, Poland, 2015.

79. Jajuga, K.; Karaś, M.; Kuziak, K.; Szczepaniak, W. Ryzyko systemu finansowego. Metody oceny i ich weryfikacja w wybranych krajach [Financial system risk. Assessment methods and their verification in selected countries]. Mater. Stud. 2017, $329,1-189$.

80. Sulich, A. Człowiek wobec zjawisk i procesów globalizacji [Man in the face of phenomenon and processes of globalization]. Eur. J. Manag. Soc. Sci. 2020, 1, 33-37. [CrossRef]

81. Frieden, J. The Backlash against Globalization and the Future of the International Economic Order. Prepared for a Policy Network Volume, the Next Phase of Globalisation: Capitalism and Inequality in the Industrialized World; Harvard University: Cambridge, MA, USA, 2018.

82. Kim, H.M.; Li, P.; Lee, Y.R. Observations of deglobalization against globalization and impacts on global business. Int. Trade Politics Dev. 2020, 4, 83-103. [CrossRef]

83. Sozosfera.pl. Rośnie Popyt Przedsiębiorstw Na OZE [The Demand of Enterprises for RES Is Growing]. Available online: https:/ / sozosfera.pl/zielona-energia/rosnie-popyt-przedsiebiorstw-na-oze/ (accessed on 9 September 2021).

84. Forsal. Opłacalność Zielonych Inwestycji [Profitability of Green Investments]. Available online: https://forsal.pl/artykuly/1387 840, oplacalnosc-zielonych-inwestycji.html (accessed on 9 September 2021).

85. PwC-ING. The Financing of Power Industry Investments in Poland. May 2011, pp. 24-25. Available online: https://www.pwc. $\mathrm{pl} / \mathrm{en} / \mathrm{publikacje/ing-finansowanie-invest.pdf} \mathrm{(accessed} \mathrm{on} 27$ October 2021).

86. Pyka, I.; Nocon, A. Negative interest rate risk. Atavism or normalization of central banks' monetary policy. Acta Univ. Lodz. Folia Oecon. 2019, 3, 89-116. [CrossRef]

87. Nocoń, A. Response System of Modern Central Banks on Banking Sector Instability; Difin: Warsaw, Poland, 2016.

88. UKNF. Report on the Activities of the UKNF and the Polish Financial Supervision Authority in 2019. Available online: https: / /www.knf.gov.pl/knf/pl/komponenty/img/Sprawozdanie\%202019.pdf (accessed on 30 June 2021).

89. Mielcarek, P. Metoda case study w rozwoju teorii naukowych [Case study method in the development of scientific theories]. Organ. Manag. 2014, 1, 105-117.

90. WKB Lawyers. WKB Zielone Finanse [WKB Green Finance]. March 2021, Legal Alert, Part III. Available online: https:/ /wkb.pl/wpcontent/uploads/2021/03/WKB-Legal-Alert_Zielone-Finanse-cz\%C4\%99\%C5\%9B\%C4\%87-3-1.pdf (accessed on 23 July 2021).

91. BNP Paribas. Strefa Zielonych Produktów [Green Products Zone]. Available online: https://www.bnpparibas.pl/strefazielonych-produktow (accessed on 22 July 2021).

92. Grabowski, M.; Kotecki, L. Green Bonds in Poland. Guide for the Issuer; Institute of Responsible Finance: Warsaw, Poland, 2020.

93. European Financial Congress. "Zielone finanse"-Nowe Spojrzenie na Finansowanie ['Green Finance'—A New Approach to Financing]; European Financial Congress. 2020, p. 4. Available online: https://www.efcongress.com/wp-content/uploads/2020 /10/publikacja_zielone_finanse-nowa-wersja.pdf (accessed on 30 September 2021).

94. EIB. EIB Energy Lending Policy. Supporting the Energy Transformation. 14 November 2019. Available online: https://www.eib. org/attachments/strategies/eib_energy_lending_policy_en.pdf (accessed on 23 July 2021).

95. EIB. Green Thread. Activity Report of the European Investment Bank in 2019. 2020. Available online: https://www.eib.org/ attachments/general/reports/eib_activity_report_2019_pl.pdf (accessed on 22 July 2021).

96. Jajuga, K.; Zabawa, J.; Daszyńska-Żygadło, K. Finansowanie Inwestycji w Energetykę Odnawialną Przez Polskie Banki [Financing of Investments in Renewable Energy by Polish Banks]. Available online: https://pab.wib.edu.pl/finansowanie-inwestycji-wenergetyke-odnawialna-przez-polskie-banki / (accessed on 26 July 2021).

97. AleBank.pl. Bez Banków ani Rusz. Raport Specjalny [You Can't Move without Banks. Special Report]. Available online: https: / / alebank.pl/raport-specjalny-bez-bankow-ani-rusz/?id=351040\&catid=32099 (accessed on 26 July 2021). 
98. Żylińska, J.; Wilkowicz, Ł. Banki Pod Presją Unijnych Ambicji. Dziennika Gazeta Prawna. Available online: https://finanse. gazetaprawna.pl/artykuly/1497905,knf-banki-zielona-polityka-ue.html (accessed on 27 July 2021).

99. Wolański, R. Wpływ Otoczenia Finansowego na Konkurencyjność Małych i Średnich Przedsiębiorstw (Impact of the Financial Environment on the Competitiveness of Small and Medium-Sized Enterprises); Wolters Kluwer Business: Warsaw, Poland, $2013 ;$ p. 25. 